\title{
DIALÉTICA DO INACABAMENTO: 150 ANOS DO LIVRO I DE O CAPITAL
}

The dialetic of incompleteness: 150 years of Marx's Capital

João Antonio de Paula *

Resumo: A partir do caráter incompleto da obra econômica de Marx, o texto investiga o sentido de se considerar o seu pensamento um todo acabado. Vários críticos, ao longo da história do marxismo, apontaram o fato de que Marx teria enfrentado impasses metodológicos no final de sua trajetória, como se tivesse vivido uma "crise criativa". $O$ artigo analisa as visões dessa derrota científica e indica as possibilidades de superação de visões em geral estreitas sobre a incompletude, para pensar o sentido de uma posição marxista na contemporaneidade.

Palavras-chave: Karl Marx. O Capital. Dialética. Teoria econômica.

Abstract: The paper investigates the possibility of considering Marxian thought as a finished whole, despite the incompleteness of Marx's economic work. Throughout the history of Marxism, several critics have pointed to the fact that Marx would have faced methodological deadlocks at the end of his career as if he had experienced a "creative crisis." The article analyzes some visions of this scientific defeat and indicates the possibilities of overcoming these narrow approaches to incompleteness in order to reflect on the meaning of a Marxist position in contemporary times.

Key-words: Karl Marx. Dialetic. Marx's Capital. Economic theory.

* Professor do Cedeplar/FACE/UFMG. Artigo recebido em 21/09/2019 e aprovado para publicação em 18/11/2019. 


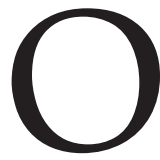
título deste ensaio remete ao importante livro de Adorno e Horkheimer seja por trazer a palavra dialética, seja pela semelhança das terminações das duas palavras - esclarecimento e inacabamento. Quanto ao mais, é possível dizer que em nada mais se parecem os dois textos, na medida em que Dialética de Esclarecimento é uma radical denúncia dos aspectos regressivos associados à ideia de "esclarecimento", de "progresso", enquanto Dialética do Inacabamento pretende discutir os vários sentidos e implicações do "inacabamento" do livro O Capital, de Karl Marx, argumentando, com um certo "que" de paradoxo, posto que, no caso da obra de Marx, este inacabamento, se não chega a ser uma virtude, impele o texto à permanente atualização, à permanente abertura para a incorporação das transformações que a realidade vai pondo, impedindo uma totalização precoce, um congelamento do que ainda não está pronto para o apaziguamento.

Ao contrário de certas interpretações, como a de José Arthur Giannotti, que atribuem o inacabamento a um impasse teórico - "Há indícios de que Marx chegara a um impasse teórico, pois a análise da gramática do capital caminhava num sentido que o obrigaria a rever sua antiga ideia de Revolução. Em poucas palavras, conforme as categorias iam se desdobrando e se aproximando de uma descrição fenomenológica da realidade do processo de acumulação capitalista, a cada passo encontravam novos obstáculos na efetivação de suas identidades pressupostas". (...) "Desde logo é sintomático que o tomo III se interrompe no capítulo sobre as classes sociais. Em vez daquela polarização das partes antagônicas que levam a superar a contradição assim realizada, ocorre uma espécie de desintegração de suas unidades pressupostas, de sorte que as categorias fibrilam e tendem a deixar de ser parâmetros de comportamento."1 $\mathrm{O}$ ponto de Giannotti é que Marx teria percebido, na medida em que avançava sua análise das contradições do capital, que "a contradição básica entre capital e trabalho, em vez de se enrijecer em polos absolutamente antagônicos, corrói o perfil de cada um desses temas." ${ }^{2}$

Daí, da crescente constatação de um impasse teórico insuperável, Marx teria, a partir dos anos 1870, consciente ou inconscientemente, adotado uma estratégia de procrastinação, de adiamento do acabamento de uma obra que, se se realizasse, seria às custas da desconstituição de seus pressupostos, da coerência teórica, política e ideológica de uma proposta - a crítica da economia política, a um tempo, e inextricavelmente, teórica e revolucionária. José Arthur Giannotti, apoia-se em sua descrição da crise

\footnotetext{
${ }^{1}$ GIANNOTTI, José Arthur. Marx. Vida \& Obra. Porto Alegre, L\&PM Editores, 2000, p. 88-89.

${ }^{2}$ Idem, p. 63.
} 
criativa que teria acometido Marx, a partir de 1870, de uma única obra - La vie de Karl Marx. L'Homme et le Lutteur - de Boris Nicolaievski e Otto Menchen-Helfen. Dizem estes biógrafos de Marx - “Após 1873, Marx jamais retomou sua antiga capacidade de trabalho. Ele continuou um leitor insaciável que sempre fora, ele tomava incontáveis notas, ele compulsava novas fontes e as organizava, mas não tinha mais a força da síntese." (...) "Marx aprendeu o russo. A Inglaterra servira para ilustrar os desenvolvimentos teóricos do Livro I de $\boldsymbol{O}$ Capital, a Rússia deveria servir de base às páginas consagradas à renda da terra no segundo volume (sic). Marx acumulou toda a documentação sobre a Rússia que pôde obter. Depois de sua morte, Engels encontrou entre seus papéis dois metros cúbicos de estatísticas russas. E não era somente por consciência científica que Marx estudou sem cessar novas fontes; de fato, ele disfarçava com isso, para ele mesmo, a paralisia de suas forças criativas". (...)."3 Há na afirmação anterior um tal arbítrio de interpretação, uma sorte de psicologismo gratuito, que dispensa maiores comentários. De todo modo, mesmo os defensores de um Marx exaurido de sua força criativa, de sua capacidade de síntese, terão dificuldade em negar estas qualidades a dois textos de Marx, produzidos neste dito período de crise criativa, que são: de 1875, Crítica do Programa de Gotha, que é, exemplarmente, uma extraordinária e única, sob certos aspectos, explicitação de características centrais do socialismo; ${ }^{4}$ e de 1881, Glosas Marginais sobre o Tratado de Adolph Wagner, que é luminosa retomada da teoria do valor em chave de síntese compreensiva, que afirmando a centralidade da categoria mercadoria como ponto de partida, como objeto de $\boldsymbol{O}$ Capital, tanto reitera a especificidade da crítica da economia política como "superação" (Aufhebung) da economia política, quanto explicita sua proposta metodológica rigorosamente dialética, no sentido de recusar qualquer ponto de partida arbitrário. Diz Marx: "Antes de tudo eu não parto de "conceitos", nem, portanto, do "conceito de valor", e por isto não devo, de modo algum, "dividir" esse conceito. De onde eu parto é da forma social mais simples em que se apresenta o produto do trabalho na sociedade atual e esta forma é a mercadoria." ${ }^{5}$

Se é fato que Marx publicou pouca coisa depois de 1870, isso não correspondeu a arrefecimento do ritmo de trabalho, que continuou intenso, constrangido pelos problemas de saúde, que o acompanharam sempre, nem significou modificação do plano geral de elaboração da "crítica da economia política", em sua ciclópica abrangência. Diz Michael Krätke “Na literatura biográfica, este último período de sua vida é, em geral,

\footnotetext{
${ }^{3}$ NICOLAIEVSKI, Boris, MENCHEN-HELFEN, Otto. La vie de Karl Marx. Trad. Francesa, Paris, Gallimard, 1970, p. 417.

${ }^{4}$ MARX, Karl. Crítica do Programa de Gotha. Trad. port., Porto, Portucalense Editora, 1971.

${ }^{5}$ MARX, Karl. "Glosas marginales al "Tratado de economia política" de Adolph Wagner" in DOBB, Maurice e outros (orgs.). Estudios sobre "El Capital". Trad. esp., México, Espanha, Argentina, Colombia, Siglo XXI Editores, 1977, p. 176.
} 
considerado como um período de fracassos. Marx, por diversas razões, fracassou na realização de sua obra prima, $O$ Capital. Teria renunciado, aceitado a derrota, reconhecendo sua incapacidade para levar a cabo seu grande projeto de crítica da economia política." (...)

“Graças aos trabalhos em andamento no âmbito da MEGA, é possível, agora, ter uma ideia mais correta e precisa do trabalho científico de Marx durante o último período de sua vida. Daqui a alguns anos, a maior parte de seus manuscritos, notas de leituras e coleções de materiais que datam deste período, estará publicada. Isto mudará provavelmente o julgamento que se tem sobre o último Marx." (...) "Porque Marx, como atestam milhares de páginas de escritos deixadas por ele, não desistiu de seu grande projeto. Continuou trabalhando com a mesma paixão, a mesma voracidade que tinha durante os quinze anos precedentes." (...) "Todos os seus escritos inéditos testemunham os esforços constantes para levar a bom termo $\boldsymbol{O}$ Capital e, sobretudo, para fornecer dele uma visão completa e perfeita. Lembremos da quase última palavra do último Marx, em dezembro de 1881, a respeito de $\boldsymbol{O}$ Capital, lacônica porém reveladora: "Seria preciso retomar tudo, inteiramente", escreve Marx a seu amigo e colaborador Danielson. De fato, ele tinha expressado essa mesma ideia dez anos antes, em 1871. Naquele momento, ele começava a trabalhar seriamente em uma tradução francesa e, ao mesmo tempo, em uma nova versão alemã do livro I." ${ }^{\prime 6}$

Se é possível concordar com Krätke, quando diz - "De fato, Marx nunca renunciou totalmente ao plano dos seis livros." ${ }^{17}$-, não é possível acompanhá-lo, nem a Michael Heinrich, quando dizem - "claramente, ele modificou a estrutura da obra, abandonando a dicotomia hegeliana do capital em geral versus os capitais individuais como o princípio de organização da obra. Consequentemente, rearranjou a estrutura de exposição de $\boldsymbol{O}$ Capital. Entre 1863 e 1882, tomou consciência do alcance e dos limites de sua teoria geral do capitalismo. No que se refere a questões estudadas no Livro III, como o crédito, o comércio, a renda fundiária, ele não concentrou solução definitiva e satisfatória. Ele decidiu, provavelmente, ampliar sua apresentação do livro sobre o capital, no qual o plano original deixava um espaço reduzido. Por exemplo, a categoria do mercado mundial já está manifestamente presente no Livro I - assim como o trecho referente à moeda mundial (ou universal) - no capítulo 3; ver também um capítulo inteiro sobre a "Diferenças nas taxas de salários nacionais", capítulo 22 do Livro $I^{8}$.

\footnotetext{
${ }^{6}$ KRÄTKE, Michael. "O último Marx e O Capital" in ALIAGA, Luciana, AMORIM, Henrique e MARCELINO, Paulo (Orgs.). Marxismo. Teoria, História e Política. trad. port., São Paulo, 2011, p. 14.

${ }^{7}$ Idem, p. 16.

${ }^{8}$ Idem, p. 16.
} 
Muito há que se discutir sobre a posição de Krätke expressa nesse último texto. Duas observações preliminares, antes de exame mais detido, sejam feitas: 1) é difícil aceitar como legítima a afirmação da existência de um "dualismo hegeliano". Ora, não há lugar para dualismos, seja em Hegel, seja em Marx. De fato, não há um "plano do capital em geral" e um "plano dos vários capitais" senão um sistema de mediações, que perfazem a tríade "generalidade - particularidade - singularidade", em que os "vários capitais" são o resultado da atuação da complexificação crescente decorrente da concorrência, isto é, das particularidades postas: pela presença do Estado, de suas políticas e incentivos; do comércio internacional e as particularidades regionais-nacionais da acumulação de capitais; do mercado mundial e das crises como soluções traumáticas e provisórias de contradições intercapitalistas e da luta de classes em escala mundial.

2) O segundo ponto a se destacar do texto de Krätke é que, no Livro I, de $O$ Capital, estão pressupostos, isto é, estão apresentados em alto grau de abstração, todas as determinações do capital, todo o conteúdo histórico-concreto, que tipificará o plano dos vários capitais, sem que isso configure efetivação das categorias que, para se realizarem, efetivamente, teriam que perfazer aquela clássica exigência - "ser unidade do diverso, ser síntese de muitas determinações" - ser, enfim, o concreto, que só pode se pôr como resultado, como totalização de totalizações.

Com efeito, o Livro I de $\boldsymbol{O}$ Capital, sob pena de extravagante contenção, não podia deixar de apresentar os variados aspectos da realidade econômica, mesmo que esta primeira apresentação só pudesse se fazer de forma abstrata, que é a forma correta de aparecimento das categorias antes de estarem postas as condições para a sua presentificação como singularidades, como realidades concretas.

Com efeito, há na tese de que a utilização do vocabulário da economia política se confunde com a explicitação de seus desdobramentos dialéticos, a exigência, algo esdrúxula, de uma espécie de "quarentena" em que certas palavras estariam impedidas de serem usadas a não ser em situações bem determinadas. Ora, a questão nesse caso, ou seja, no referente à exposição dialética de conceitos, não se resume ao vocabulário utilizado, mas à explicitação do sistema de mediações, que permite a apreensão do concreto.

Neste texto, sustenta-se, concordando com Krätke, que Marx não abandonou o plano da crítica da economia política em seis livros - capital, propriedade fundiária, trabalho assalariado, Estado, Comércio Externo, Mercado mundial e as crises - e sustenta-se, também, contrariamente ao que dizem Krätke e Michael Heinrich, em apoio à posição de Rosdolsky, que Marx não abandonou a estratégia que conduziu a exposição da crítica da economia política a partir do modo necessário de aparição das categorias, de totalidades abstratas, como capital em geral, aos quais, mediante 
o trabalho das mediações, se realizarão como totalidades concretas, como vários capitais, como singularidades resultantes do movimento concreto da história.

Esta polêmica foi reportada por Paul Burkett, em artigo "Some comments on 'Capital in general and the structure of Marx's capital'" - que, tendo relevância, adota qualificação das correntes em disputa que merece reparo. Se é exata a caracterização como "Analítica" da corrente que "nega que a dialética jogue qualquer papel proveitoso ou essencial em $O$ Capital ou que seja um instrumento válido para a economia política marxiana hoje" "; chamar "Fundamentalista" a corrente que defende a centralidade da dialética em $\boldsymbol{O}$ Capital, está longe de ser uma clarificação isenta de preconceitos, ao evocar certos aspectos negativos associados aos "fundamentalismos" - fanatismo, sectarismo, irracionalismo. Não se trata de uma disputa entre uma corrente "analítica" e uma corrente "fundamentalista", mas, entre uma corrente "analítica" e uma corrente "ontológica", que é esse o ponto central a distinguir as duas correntes; a compreensão de que a dialética não é só um método, uma sorte de expediente epistemológico, mas, como na lição de Hegel, o resultado do efetivo entrelaçamento entre lógica e ontologia; "a lógica hegeliana não é uma lógica no sentido escolar da palavra, não é uma lógica formal, mas uma indissolúvel unidade espiritual de lógica e ontologia. Por um lado, as verdadeiras conexões ontológicas recebem em Hegel a sua expressão adequada no pensamento tão-somente na forma de categorias lógicas; por outro lado, as categorias lógicas não são concebidas como simples determinações do pensamento, mas devem ser entendidas como componentes dinâmicos de movimento essencial da realidade, como graus ou etapas no caminho do espírito para realizar a si mesmo" 10 .

Por sua vez, o pensamento marxiano sobre ontologia, sua ontologia, tem seu ponto de partida em Hegel, na filosofia hegeliana - "E essa, como vimos, move-se dentro de uma certa unidade, determinada pela ideia do sistema, entre ontologia lógica e teoria do conhecimento; o conceito hegeliano de dialética implica, no próprio momento em que se põe a si mesmo, uma semelhante verificação e, inclusive, tendo a fundir uma coisa com a outra." 11 .

Trata-se aqui, não só de afirmar a inextricável relação entre a filosofia hegeliana e o pensamento de Marx, o que significa dizer, afirmar a centralidade da dialética, apropriação específica que Marx faz da dialética hegeliana:

\footnotetext{
${ }^{9}$ BURKETT, Paul. "Some comments on 'Capital in general and the structure of Marx's capital'. In Capital $\mathcal{E}$ Class, v 44, n. 2, 1991, p. 49.

${ }^{10}$ LUKÁCS, Georg. Ontologia do Ser Social. A Falsa e a Verdadeira Ontologia de Hegel. Trad. Port., São Paulo, Livraria Editora Ciências Humanas, 1979, p. 27.

${ }^{11}$ LUKÁCS, Georg. Ontologia do Ser Social. Os Princípios Ontológicos Fundamentais de Marx. Trad. port., São Paulo, Livraria Editora Ciências Humanas, 1979a, p. 11.
} 
"não se trata absolutamente de dizer que a dialética é a última palavra ou que está acima de toda crítica. O que queremos dizer é simplesmente que toda crítica de $\boldsymbol{O}$ Capital que não toma a sério a dialética como discurso da contradição só pode conduzir a uma regressão. É esta regressão, esta volta aquém de Marx que está em questão, não o projeto de ir além, o qual, pelo contrário, é a tarefa de todos nós."12.

Se não é o caso de falar de abandono da dialética no referente à tese de Heinrich sobre uma mudança que Marx teria operado em sua metodologia de apresentação da crítica de economia política, entre 1859 e 1867, essa mudança, se tiver, de fato, ocorrido, tem profundas implicações sobre a compreensão do conjunto da obra de Marx, e sua crítica da economia política. Diz Burkett - "Em oposição a Rosdolsky, Heinrich sugere que entre a publicação da Crítica da Economia Política e a redação de $O$ Capital, houve uma mudança básica no tratamento metodológico de Marx para analisar o capitalismo. Em particular, a tentativa de Marx de manter a distinção conceitual entre 'capital em geral' e 'vários capitais' desmoronou e Marx foi obrigado a trazer elementos atinentes ao plano dos 'vários capitais' para a análise de questões pertinentes ao plano do 'capital em geral'. Baseado parcialmente nos manuscritos de Marx de 1861-63, Heinrich argumenta que o problema básico com o 'capital em geral' é que ele 'envolve conteúdos específicos, nomeadamente, todas as características que aparecem no movimento real do capital, na concorrência, enquanto, ao mesmo tempo, que seu conteúdo tinha sido apresentado como um nível específico de abstração. Mais especificamente, o 'capital em geral' é 'abandonado porque não é possível elaborar todas as determinações da forma (Formbestimmungen) indispensáveis para a transição da 'generalidade' para o 'movimento efetivo' prescindindo do movimento dos muitos capitais'."13.

A marcha da exposição deste ensaio será a seguinte: no item que se segue, "Uma viagem completa", vai-se argumentar que o Livro I de $\boldsymbol{O}$ Capital, sobre o qual Marx elaborou pelo menos três edições completas, deve ser considerado como acabado, o que não o eximiu de continuar trabalhando nele até o final de sua vida, seja complementando-o, seja suplementando-o, isto é, adicionando-lhe elementos novos. Esta efetiva completude do Livro I, contudo, não é garantia que se tenha pleno acesso ao que seu autor pretendia. Só agora, com a publicação da MEGA, de todos os materiais referentes a $\boldsymbol{O}$ Capital, os textos publicados, as versões dos textos não utilizadas, a marginalia, as notas, a correspondência e o conjunto do aparato crítico, será possível a elaboração de uma "edição crítica", seja do Livro I, seja do Livro II e do Livro III, que perfazem, de fato, um conjunto e só podem ser adequadamente compreendidos tanto em suas conexões conceituais, lógicas, efetivas, quanto nas lacunas, nas ausências,

${ }^{12}$ FAUSTO, Ruy. Marx: Lógica \& Política. Tomo I, São Paulo, Editora Brasiliense, 1983, p. 122.

${ }^{13}$ BURKETT, op. cit. p. 50. 
nas incompletudes resultantes do inacabamento da obra em seu conjunto.

Nesse sentido, é possível dizer, mesmo com relação ao Livro I, publicado há 150 anos, que o muito que, efetivamente, é possível saber sobre ele, não elimina as muitas áreas de sombra, que o fazem, relativamente, ainda, um livro a ser decifrado em todos os seus significados e implicações.

A segunda parte deste ensaio tem o título - "As outras viagens" - e busca mostrar as alterações no pensamento de Marx, que vão se refletir em sua obra, que de um momento fortemente eurocêntrico, adepto da visão de Hegel sobre os "povos sem história", transitou, a partir de seu envolvimento com a Associação Internacional dos Trabalhadores, desafiado a compreender a luta de classes em escala mundial, as diferenças entre o capitalismo no centro e na periferia, para uma posição, efetivamente, internacionalista, crítica e revolucionária.

Finalmente, a terceira parte do ensaio, "Qual é mesmo o nome do País?", vai discutir o sentido essencial do livro $O$ Capital, sua estrutura expositiva, seus propósitos e lugar na história, partindo do suposto de que ele é o livro mais importante do nosso tempo, no sentido em que abarca, de modo abrangente e compreensivo, as grandes questões contemporâneas resultantes do domínio do capital.

\section{Uma Viagem Completa: O Livro I de O Capital}

A viagem da qual se fala aqui é a do capital. Nessa outra odisseia, que é $\boldsymbol{O}$ Capital, como bem viu Karel Kosik ${ }^{14}$, acompanha-se, um novo périplo, não de um herói, astucioso e curioso, Ulisses, mas de uma relação social, que se pondo como coisa, mercadoria, condena tudo a sua volta à uma sôfrega busca de maior poder sobre a vida humana, transformada em permanente trabalho para o enriquecimento, para a acumulação de riquezas, de dinheiro, dos que subordinam os condenados ao trabalho, alienado e compulsório. Ao final da Odisséia, dez anos após a Guerra de Tróia, Ulisses retornou à sua Ítaca natal, e lá reencontrou a família, a mulher, o trono, vingou-se de seus inimigos e se deixou apaziguar. Ao final da odisseia da mercadoria, transformada em capital, um capital que se acumulou como fim em si mesmo, na vigência desta forma limite de "má infinitude", de irracionalidade com fortes conteúdos regressivos, o capital, desmesurado, incapaz de conter sua hybris, põe em marcha os elementos disruptivos, que, em certo momento, se apresentarão como crise, como violência, como destruição.

\footnotetext{
${ }^{14}$ KOSIK, Karel. A Dialética do Concreto. Trad. port., 2ª edição, Rio de Janeiro, Paz e Terra, 1976.
} 
O tema da Odisséia teve considerável importância na cultura europeia da segunda metade do século XVIII, impactando a literatura, a filosofia. Diz Kosik - "Marx e Hegel, na construção das suas obras, partem de um motivo simbólico comum, difuso na atmosfera cultural do seu tempo. Este motivo próprio da época da obra literária, filosófica e científica é a odisseia. $\mathrm{O}$ sujeito (o indivíduo, a consciência individual, o espírito, a coletividade) deve andar em peregrinação pelo mundo e conhecer o mundo para conhecer a si mesmo. O conhecimento do sujeito só é possível na base da atividade do próprio sujeito sobre o mundo; o sujeito só conhece o mundo na proporção em que nele intervém ativamente, e só conhece a si mesmo mediante uma ativa transformação do mundo." ${ }^{15}$.

De tal modo que brilha o corolário de que a odisseia, significa: conhecer o mundo é transformá-lo, mediante uma atividade crítico-prática superadora da alienação, da má-fé, da venalidade. Esta é ideia que já aparecera luminosa, em Marx, na II a tese sobre Feuerbach, de 1845/46 - “Os filósofos, até aqui, não têm feito, senão interpretar o mundo, de várias maneiras; trata-se, de fato, de transformá-lo." ${ }^{16}$.

A teoria literária identificou a existência de duas modalidades de epopeias, as epopeias naturais, ou verdadeiras, e as epopeias artificiais, ou de imitação. Epopeias naturais são: a Ilíada e Odisséia, o Mahabharata, o Ramayana, os Nibelungos, o Poema do Cid. Epopéias de imitação: a Farsália, A Tebaida, A Divina Comédia, Orlando Furioso, A Araucana, Os Lusíadas. Não há propósito em listá-las todas, seguem-se alguns exemplos de epopeias latinas -a Eneida, de Virgílio,e a Farsália, de Lucano; italianas - A Divina Comédia, de Dante, Orlando Furioso, de Ariosto; Jerusalém Libertada, de Torquato Tasso; portuguesas - Os Lusíadas, de Camões; espanhola - Poema do Cid; alemãs - Os Nibelungos; A Messíada, de Klopstock; francesas - A Canção de Rolando, A Henriada, de Voltaire; inglesas - O Poema de Beowulf; O Paraíso Perdido de Milton ${ }^{17}$.

Karel Kosik chamou a atenção para o fato de que a epopeia desbordou seu campo formal influenciando tanto a forma romance, em particular o chamado romance de formação, quanto a filosofia, quanto o pensamento crítico: "A história de um coração humano", de Rousseau (Emile ou Da Educação) e o Bildungsroman alemão na clássica versão do Wilhelm Meister, de Goethe; ou na versão romântica do Heirinch von Ofterdingen, de Novalis; a Fenomenologia do Espírito, de Hegel, e O Capital, de Marx, são exemplos da forma "odisseia" nos vários campos de criação cultural."18.

\footnotetext{
${ }^{15}$ Idem, p. 165.

${ }^{16}$ MARX, Karl. La Ideologia Alemana. Trad. esp., 4ª edição, Montevidéo/Barcelona, Ediciones Pueblos Unidos/Ediciones Grijalbo, 1972, p. 668.

17 SAINZ DE ROBLES, Federico Carlos. Ensayo de un Diccionario de la Literatura. Tomo I, Madrid, Aguilar Ediciones, 1949, p. 429-433.

${ }^{18}$ KOSIK, op. cit. p. 166.
} 
Neste ensaio, cujo propósito é mostrar que o inacabamento de $\boldsymbol{O}$ Capital não é simplesmente um defeito, uma lacuna, mas tem implicações heurísticas, a leitura de um texto recente de Miguel Vedda, sua análise da presença de Goethe na filosofia de Ernst Bloch, veio a calhar. Com efeito, o que Vedda nos mostra é o quanto o Fausto, de Goethe, é uma forma superior de apresentação dialética na medida em que não se contenta com totalizações limitadas, com apaziguamentos de ocasião - "Goethe foi sempre uma influência decisiva na filosofia de Bloch, Frederic Jameson escreveu que a íntegra obra blochiana poderia ser interpretada como um extenso comentário sobre o Fausto. O empenho fáustico em rechaçar qualquer satisfação limitada é, para Bloch, uma das imagens mais características de impulso utópico; a perpétua inquietude do personagem goetheano, que busca sempre um novo auge depois do já alcançado, constitui a superação da antítese plasmada nos extremos, igualmente parciais, do idealismo abstrato (Dom Quixote) e do conformismo filisteu (O Ulisses homérico, depois de seu retorno a Ítaca): alheio a toda desmesura unilateral, Fausto transcende os limites da realidade dada, porém sem negá-la, abstratamente, antes, conservando-a como herança válida." ${ }^{19}$.

É este exemplo, o da permanente inquietude do Fausto, que se quer invocar aqui, como análogo ao movimento de $\boldsymbol{O}$ Capital. Também ali não há um desaguar numa plenitude apaziguadora. Com efeito, aquela paz, no mundo do capital, só se alcança com a sua destruição, isto é, com a revolução emancipatória.

O Capital, Livro I, foi publicado em 1867, em sua primeira versão alemã. Entre junho de 1872 e maio de 1873, apareceu uma segunda edição alemã, com significativas modificações nos primeiros quatro capítulos e no ponto 2 do capítulo VII ${ }^{20}$. Em meados de 1873, a segunda edição em alemão do Livro I foi publicada num volume. A versão francesa do livro I, tradução de Joseph Roy, apareceu em fascículos, entre agosto de 1872 e novembro de 1875, tendo todo o trabalho sido supervisionado por Marx. Sobre a qualidade dessa edição há juízo severo de Pedro Scaron. Diz ele - "Cabe considerá-la, para o bem e para o mal, como uma nova versão, a terceira, do tomo I de $\boldsymbol{O}$ Capital. Para o mal porque Marx, que, estimava os franceses como revolucionários práticos mas não como teóricos, simplificou - por momentos adoçou - muitas das passagens mais complexas e profundas do original" (...) "Para compensar, em certa medida, essas simplificações, Marx enxertou no tronco principal do texto francês uma série de agregados, em sua maior parte muito valiosos, e efetuou em algumas passagens

\footnotetext{
${ }^{19}$ VEDDA, Miguel. La Sugestión de lo concreto. Estudios sobre Teoria Literaria Marxista. Buenos Aires, Editorial Gorla, 2006, p. 216.

${ }^{20}$ FINESCHI, Roberto. Un nuovo Marx. Filologia e interpretazione dopo la nuova edizione storico-critica (MEGA2). Roma, Carocci editore, 2008, p. 109.
} 
uma reelaboração que lembra, ainda que não se iguale, ao realizado na segunda edição alemã." ${ }^{21}$.

O Livro I teve uma terceira edição alemã, que saiu em 1883, depois da morte de Marx, sem que ele tivesse acompanhado o trabalho de edição, uma quarta edição em alemão, em 1890, que acabou sendo uma espécie de edição "definitiva", ainda que não o seja, na medida em que tanto a $3^{\mathrm{a}}$, quanto a $4^{\mathrm{a}}$ edição alemãs não foram editadas pelo seu autor. Nesse sentido, tem fortes razões Pedro Scaron para defender que a edição a ser considerada "definitiva" do Livro I de $O$ Capital, deva ser a $2^{\underline{a}}$ edição alemã, de 1873, não só porque foi a última a ser escrita e revisada por ele, quanto por apresentar importantes aperfeiçoamentos quando comparado com a $1^{\underline{a}}$ edição de 1867.

O fato é que, apesar desta relativa profusão, deste contínuo debruçar-se sobre a obra, Marx nunca ficou inteiramente satisfeito com o resultado e continuou trabalhando sobre o Livro I até o final de sua vida. De tal modo, que é o caso de dizer que o livro I de $O$ Capital foi escrito, reescrito, revisado, complementado, suplementado e, ainda assim, permaneceu inconcluso.

Não há propósito em insistir, mais do que o necessário, que o Livro I de $O$ Capital é a realização do momento chave do projeto de elaboração da crítica de economia política, no sentido de revelar um objeto em suas conexões internas, em suas múltiplas determinações, apresentado segundo o modo necessário de exposição das categorias perfazendo o caminho de suas mediações do imediato da generalidade, passando pelas instâncias intermediárias das particularidades, até sua plena realização como singularidade, como concreto. Essa sequência silogística da exposição dialética, foi explicitada por Marx, tanto na Introdução à Crítica da Economia Política, de 1857, que é, de fato, a Introdução aos Grundrisse, quanto no corpo daquele texto - "caminho lógico e exigente a exposição da dialética do capital apresenta-se como o roteiro básico do discurso marxiano em $O$ Capital. Nos Grundrisse Marx é explícito na apresentação do seu roteiro metodológico, roteiro que terá modificado quando da redação de $\boldsymbol{O}$ Capital sem que isto signifique alterações da lógica dialética da exposição.

\section{Generalidades}

1. Formação do capital a partir do dinheiro

2. Veiculação do capital

3. Singularidade do capital - capital e lucro, capital e juros

${ }^{21}$ SCARON, Pedro. "Advertencia del Traductor" in MARX, Karl. El Capital, Tomo I/Vol. 1, Livro I, El Proceso de Producción del Capital, México, Espanha, Argentina, op. cit., 1977a, p. VIII. 


\section{Particularidades}

1. Acumulação de capital

2. Concorrência entre os capitais

3. Concentração de capitais

\section{Singularidades}

1. O capital como crédito

2. O capital como capital por ações

3. O capital como mercado monetário." ${ }^{22}$.

Trata-se de silogismo dialético, que, tendo sido apropriado de Hegel, foi transfigurado para expressar, não a marcha do espírito, mas o movimento do mundo dominado pelo capital, o mundo das mercadorias, em suas variadas estações, circunvoluções, metamorfoses, totalizações. Com efeito, a estrutura expositiva de $\boldsymbol{O}$ Capital, Livro I, está organizada a partir de um conjunto de totalizações que vão se pondo como círculos concêntricos, desde um nível máximo de abstração, em que todas as categorias estão pressupostas, passando pelas várias totalizações parciais, em que as categorias vão sendo postas, até que o todo seja reconstituído, não mais como totalidade abstrata, pressuposta, mas como totalidade posta, complexa, concreta, como resultado do trabalho da história.

A marcha da exposição de $O$ Capital, Livro I, vai do abstrato ao concreto, dos níveis crescentes de aparição e desdobramento das determinações do objeto. São várias as totalizações categoriais presentes no Livro I. A primeira totalização encontra-se na própria abertura do livro, em sua primeira oração, que como um raio, numa única cintilação, expõe toda a complexa trama que vai se desenrolar: "A riqueza das sociedades em que domina o modo de produção capitalista se apresenta como um "enorme acúmulo de mercadorias", e a mercadoria individual como a forma elementar dessa riqueza. Nossa investigação, por conseguinte, só inicia com a análise da mercadoria." ${ }^{23}$.

E, então, os principais elementos do drama foram apresentados - a mercadoria, forma elementar da riqueza do capitalismo, e a acumulação de mercadorias como a forma da riqueza no modo de produção capitalista. A partir daqui, e até o fim, até o fechamento do Livro I, e dos inacabados Livros II e III de $\boldsymbol{O}$ Capital, assistir-se-á às várias encarnações do verdadeiro Vautrin, $\boldsymbol{O}$ Capital, mais insidioso e perverso que o personagem de Balzac. Na Comédia Humana, tão povoada, quanto qualquer país real, Vautrin faz

\footnotetext{
${ }^{22}$ PAULA, João Antonio. Crítica e Emancipação Humana. Ensaios Marxistas. Belo Horizonte, Autêntica Editora, 2014, p. 157-158.

${ }^{23}$ MARX, Karl. El Capital. Tomo I/Vol. 1, Libro I. O Proceso de Producción del Capital. Trad. esp., tradução de Pedro Scaron. 5a edição, México, Espanha, Argentina, Siglo XXI Editores, 1977a, p. 43.
} 
as vezes do mal personificado, potente e ubíquo, que acompanha como uma sombra, como uma forma de luz às avessas, como força negativa. "Vautrin aparece do mesmo modo imprevisto e misterioso que Mefistófeles no Fausto de Goethe, ou Lúcifer no Caim de Byron. E a função de Vautrin na Comédia Humana de Balzac é idêntica à de Mefistófeles nos mistérios de Goethe e Byron." (...) "aos olhos de Goethe, a grande transformação do mundo de Renascimento em diante tem o valor positivo e Mefistófeles não é senão "uma parte daquela força que quer sempre o mal, mas fez sempre o Bem." Para Balzac esse Bem não vive agora a não ser nos sonhos da fantasia. O raciocínio mefistofélico de Vautrin nada mais é que a formulação brutal e cínica disso que nesse mundo todos fazem, todos devem fazer, se não quiserem perecer." ${ }^{24}$.

A aparição de Vautrin, que se apresentará com outros nomes, em outros momentos da Comédia Humana, é relativamente discreta. Na pensão de Madame Vauquer, em Tio Goriot, Vautrin é o tentador de Rastignac, é o mestre de seu aprendizado de ascensão social, abstraída de todo escrúpulo ou moralidade. Sua aparição em Ilusões Perdidas, e Esplendores $e$ Misérias das Cortesãs é revestida de intensidade disruptiva. Agora não se trata mais de apenas ascender socialmente, o que se busca é dominar a cidade, Paris, colocá-la aos pés do seu protegido, pelo talento, pela volúpia pelo poder e pela glória. Rastignac, nesse sentido, é uma versão pálida da voracidade de Lucien de Rubempré. Vautrin, que se apresenta ora como um padre espanhol - Carlos Herrera, ora como Jacques Collin, o "engana-a-morte" - é personagem dos mais complexos entre os inúmeros criados por Balzac. Houve quem não o tenha apreciado, tomando-o como destituído de substância efetivamente humana. Houve também quem, como Paul Flat, o tenha visto como - "a maior criação de Balzac, mas mesmo assim lhe reconhecem um caráter abstrato, simbólico": "Sua criação mais gloriosa, a que o classifica sem par entre os modernos e de fato um rival não igualado de Shakespeare... Vautrin pertence a essa categoria de personagens... nos quais os criadores de excepcional gênio tentaram encarnar os poderes cegos que conduzem o mundo. (...)"25.

É exatamente a partir dessa última expressão - "os poderes cegos que conduzem o mundo" - que a associação que se busca aqui entre Vautrin e o Capital se faz mais visível. Balzac surpreende, exatamente, o momento em que o dinheiro, o capital tomavam conta do mundo, a vitória do mundo da mercadoria sobre o mundo do Antigo Regime. No centro deste novo mundo, o dinheiro, o capital, a mercadoria, as criaturas de Vautrin, o poder cego que comanda o mundo com os olhos viciosos da

${ }^{24}$ LUKÁCS, Georg. Ensaios sobre Literatura. Trad. Port., Rio de Janeiro, Editora Civilização Brasileira, 1965, p. 110-111.

${ }^{25}$ RONÁI, Paulo. "Introdução" a Esplendores e Misérias das Cortesãs in BALZAC, Honoré de. Op. cit., 1956, p. 11. 
corrupção, da venalidade. Luciano de Rubempré, afinal, se vê derrotado e comete suicídio. Deixou testamento e carta em que se confessa e revela o seu Mefistofélico protetor - Vautrin/Carlos Herrera/Jacques Collin. Em carta dirigida ao Padre Herrera Lucien diz: “O senhor descende de Adão por aquela linha em que o diabo continuou a soprar o fogo cuja primeira faísca fora lançada sobre Eva. Entre os demônios dessa filiação, aparecem, de vez em quando, alguns terríveis de organizações vastas, que resumem todas as forças humanas, semelhantes a esses febris animais de deserto cuja vida exige espaços imensos." (...) "Dotados de um imenso poder sobre as almas ternas, eles as atraem e trituram. No gênero, é grande e belo. É a planta venenosa de cores ricas que fascina as crianças nos bosques. É a poesia do mal." (...) Adeus pois, adeus, grandiosa estátua do mal e da corrupção! ${ }^{26}$.

O Capital é como a Comédia Humana, que acompanhou as diversas encarnações de Vautrin, isto é, de suas criaturas - o dinheiro, a mercadoria. A primeira aparição do capital é como mercadoria, depois ela experimentará sua primeira metamorfose, desdobrando-se em dinheiro, o qual, apropriando-se de uma mercadoria especial, a força do trabalho, vai se transformar em capital. Mas, antes dessa nova totalização, a que reúne mercadoria-dinheiro-capital, há uma outra e decisiva totalização, que é a da forma do valor. Esta problemática, a da forma do valor, é a novidade especificamente marxiana que Marx trouxe para o que se pode chamar de teoria clássica do valor trabalho.

Isaac Rubin mostrou que Marx herdou da teoria clássica do valor duas questões - a referente à substância do valor e a sobre a magnitude do valor. Marx não se limitou a dar as mesmas respostas que os clássicos deram às estas questões, modificando-as significativamente, no sentido de maior precisão tanto sobre a questão da substância, quanto sobre a questão da magnitude; o valor de uma mercadoria para Marx é uma substância social, produzida pela dimensão abstrata do trabalho, isto é, é o resultado do fato de que todo trabalho humano é fragmento de trabalho humano em geral; e que a magnitude do valor de uma mercadoria é o tempo de trabalho socialmente necessário para produzi-la. Com efeito, Marx aperfeiçoou a teoria do valor trabalho, mas foi além disso, ele transformou a problemática do valor ao introduzir a questão da forma do valor, questão totalmente alheia à teoria clássica do valor. Esta problemática, que apareceu na $1^{\text {a }}$ edição do Livro I de $\boldsymbol{O}$ Capital, como um apêndice, foi reelaborado na $2^{\underline{a}}$ edição, vindo a fazer parte, como item 3, do capítulo sobre a mercadoria: "A forma do valor ou o valor da troca". O procedimento aqui é apreender a forma do valor, isto é, acompanhar os modos como as trocas vão se dar, de uma troca simples, isolada e fortuita, passando pela generalização do

${ }^{26}$ BALZAC, Honoré. Esplendores e Misérias das Cortesãs. Trad. port., vol. IX. A Comédia Humana. Rio de Janeiro. Porto Alegre/São Paulo, Editora Globo, 1956, p. 355. 
processo de trocas, até a forma dinheiro do valor, que é a forma mais universal em que o valor pode se apresentar ${ }^{27}$. Para explicitar algo que nem sempre fica claro nesse momento da exposição de $\boldsymbol{O}$ Capital. Ao contrário do que parecem acreditar certas teses, que se apegaram à ideia de que a primeira seção do Livro I de $\boldsymbol{O}$ Capital, seus três primeiros capítulos, diz respeito à uma suposta "sociedade mercantil simples", não há tal em $O$ Capital. Marx, não vê necessidade de lançar mão de uma etapa prévia ao capitalismo, o mundo de Robinson Crusoé, um "estado rude e primitivo", para postular as "condições de possibilidade de surgimento do capitalismo", antes que existisse capital. Marx, ao contrário, parte do capitalismo, do capitalismo plenamente constituído, da universalização do sistema de trocas, só que faz isso considerando a realidade do capitalismo em suas formas mais abstratas de existência, como pressuposições. É por isso que, logo no Capítulo I, não só pode aparecer a forma dinheiro do valor, como a forma preço do valor: "A expressão relativa simples do valor de uma mercadoria, por exemplo, do pano, na mercadoria que já funciona como mercadoria dinheiro, por exemplo no ouro, é a forma de preço. A "forma de preço", no caso do pano será, por conseguinte:

$20 \mathrm{~m}$. de pano $=2$ onças de ouro

ou melhor, se a denominação monetária de duas onças de ouro é duas libras esterlinas,

$2 \mathrm{~m}$. de pano $=2$ libras esterlinas." ${ }^{28}$.

Ora, trata-se aqui, de apreender a forma preço como pressuposição, já que sua efetiva posição, implicaria em, por exemplo, pôr o Estado, como gestor e emissor de dinheiro de curso legal, como a libra esterlina, por exemplo. Nessa altura da exposição, no âmbito do Livro I de $\boldsymbol{O}$ Capital, não só não é possível pôr, concretamente, a questão do preço, porque ausentes, ainda, todas as determinações necessárias para a entrada em cena da concorrência, dos vários capitais, que mesmo no âmbito do Livro III de $\boldsymbol{O}$ Capital, não pode ter efetiva concretização por estarem ausentes dimensões essenciais da dinâmica concreta do capital - o Estado, o comércio externo, o mercado mundial e as crises, tal como Marx projetava dar sequências à crítica da economia política.

A segunda seção do Livro I de $O$ Capital é composta de um único capítulo, o IV - "Como o dinheiro se transforma em capital" - que é uma nova totalização, ainda abstrata, do capital. A descoberta de que uma mercadoria, a força do trabalho, tem, e só ela tem, como seu valor de uso, gerar outros valores e mais valor, dissipou o segredo, expôs a gênese da mais

${ }^{27}$ RUBIN, Isaak. Ensayos sobre la Teoria Marxista del Valor. Trad. esp., Buenos Aires, Cuadernos Pasado y Presente, n. 53, 1974.

${ }^{28}$ MARX, 1977a, op. cit. p. 86. 
valia, abrindo caminho tanto para a explicitação das formas específicas de extração da mais valia, quanto para o termo final da primeira viagem completa do capital, para as condições concretas da acumulação de capital, a realização do desideratum essencial do capitalismo.

A sétima e última seção do Livro I de $\boldsymbol{O}$ Capital, é composta de 5 capítulos que realizam, tanto do ponto de vista da forma, como do conteúdo, a síntese da odisseia da mercadoria, sua realização como acumulação de capital a partir de rigorosa apresentação dialética. A ordem da exposição desta seção segue a tríade silogística - generalidade, particularidade, singularidade que no referente à acumulação de capital se põe assim: capítulo XXI - a Reprodução Simples, isto é, as condições da possibilidade de qualquer processo de acumulação; capítulo XXII - Transformação do mais-valor em capital, capítulo que põe as variadas formas, inclusive as não canônicas, as que transgridem as exigências da equivalência nas trocas, as formas particulares de extração da mais valia e de acumulação de capital, diz Marx: "Ao tratar da produção da mais valia, temos pressuposto sempre que o salário tem um valor pelo menos igual ao da força de trabalho. A redução compulsória do salário abaixo desse valor, entretanto, desempenha na prática papel demasiadamente importante para não nos determos por um momento na sua análise. Dentro de certos limites, essa redução transforma efetivamente o fundo de consumo necessário à manutenção do trabalhador em fundo de acumulação de capital." ${ }^{29}$.

Este trecho, extraído do Livro I de $\boldsymbol{O}$ Capital, no âmbito do "capitalismo geral", faz explícita mobilização da questão, que, em sua particularidade, em sua transgressão da troca de equivalentes, é problemática adscrita ao âmbito da concorrência intercapitalista, ao plano dos "vários capitais", sem que isso traia a rigorosa demanda da lógica dialética da exposição. Com efeito, o que Marx disse textualmente é - esta questão é demasiadamente importante no processo de acumulação real do capital para que possa ser omitida, mesmo que todas as determinações necessárias para a justa exposição da questão não estejam ainda integralmente postas. Omitir a questão das formas espúrias, mas frequentes e importantes, de acumulação decorrentes da transgressão das trocas de equivalentes, do roubo efetivo do fundo de consumo dos trabalhadores, para garantir uma sorte de pureza expositiva, seria não só uma extravagância, uma fetichização do método, mas um empobrecimento do conteúdo da matéria em tela.

O capítulo XXIII do Livro I de $\boldsymbol{O}$ Capital, "A Lei Geral da Acumulação Capitalista", é o momento conclusivo da síntese do processo de produção do capital, momento de singularidade da tríade silogística, em que o capital, finalmente, põe as determinações concretas, que no capítulo I só podiam

${ }^{29}$ MARX, Karl. O Capital, Livro I, vols. 1 e 2, trad. port., tradução de Reginaldo Sant'Anna, Rio de Janeiro, Civilização Brasileira, 1968, p. 696-697. 
aparecer como pressuposições. Agora, ganha concretude histórica, a formulação que abre $\boldsymbol{O}$ Capital - a riqueza no modo de produção capitalista pode ser, finalmente, posta: todas as contradições contidas na mercadoria apresentaram-se, desdobraram-se, realizaram a primeira totalização global do capital, a produção do capital em geral. Além do capítulo XXIII, a seção $7^{a}$ do Livro I de $\boldsymbol{O}$ Capital ainda conta com mais dois capítulos - o XXIV, "A Chamada Acumulação Primitiva do Capital"; e o XXV, "Teoria Moderna da Colonização". Estes dois últimos capítulos podem ter algo de desconcertante para os que se apegam a narrativas lineares. Marx, em O Capital, contrariou absolutamente a linearidade deixando para os dois últimos capítulos matéria que, cronologicamente, antecederia o processo da produção do capital, isto é, as condições históricas de seu surgimento, a gênese histórica do modo de produção capitalista. A marcha da exposição de $\boldsymbol{O}$ Capital não é do pré-capitalismo ao capitalismo plenamente constituído, seguindo uma outra estratégia expositiva: das condições mais abstratas, genericamente universais de existência do capital, às formas mais concretas de sua existência tendo de permeio um sistema de mediações, que vai pondo, sistematicamente, as determinações que irão enriquecer as categorias até que se realizem como universais-concretas, como singularidades.

Nesse sentido, os capítulos XXIV e XXV não estão deslocados, não estão fora do lugar, senão que devem ser entendidos como fazendo parte do momento da concreticidade do processo de produção do capital, aquele que deve abarcar a singularidade capital incluída aí a sua própria formação histórico-concreta, como acumulação primitiva do capital.

A edição de Maximilien Rubel do Livro I de $\boldsymbol{O}$ Capital, foi feita a partir de tradução francesa, de Joseph Roy, que saiu inicialmente em fascículos, entre 1872 e 1875 . Rubel adotou procedimento que tem algo de arbitrário ao inverter a ordem do último item do Livro. Argumentou ele que esta era a intenção original de Marx, que ele não pôde realizar por temer interferência da censura, já que o capítulo que fechava, originalmente, o livro era uma apaixonada conclamação à revolução social. Diz Rubel - $\boldsymbol{O}$ Capital é encerrado em todas as edições anteriores com um capítulo intitulado "A Teoria Moderna da Colonização", procedido de um capítulo sobre "A Tendência Histórica da Acumulação Capitalista". Um exame atento dessas páginas sugere que Marx inverteu a ordem dos dois capítulos no momento da publicação. Ele teria agido desse modo - por ele mesmo ou por exigência de seu editor - para enganar a desconfiança da censura. Os parágrafos apocalípticos da conclusão foram retirados do final do volume e substituídos por considerações mais professorais." ${ }^{30}$.

\footnotetext{
${ }^{30}$ RUBEL, Maximilien. "Notice" in MARX, Karl. Ouvres Economie I (org.) RUBEL, Maximilien, Paris, Bibliothèque de la Pléiade, NRF, Gallimard, 1965, p. 541.
} 
Arbitrário ou não, o reordenamento do texto promovido por Rubel permite restaurar, em sua integralidade, o plano de exposição do Livro I, que tem início com a mercadoria, e é encerrado com o capítulo "Tendência História da Acumulação Capitalista", que em versões correntes do texto aparece como item 7 do capítulo sobre "Acumulação Primitiva do Capital". Neste texto, Marx diz que o capitalismo - "chegado a certo grau de desenvolvimento, esse modo de produção gera os meios materiais de seu próprio aniquilamento. A partir desse momento agitam-se no seio da sociedade forças e paixões que se sentem acorrentadas por ele. Tem de ser destruído e é destruído." ${ }^{31}$. Em "Tendência Histórica da Acumulação Capitalista", é todo o processo de produção do capital que se apresenta, como capital em geral: estão supostas aí as classes sociais, a luta das classes como lutas entre o capital e o proletariado tomados em suas formas universais, como generalidades destituídas das particularidades regionais, culturais, da diferenciação por gênero, por grau de informação e politização, por experiências de luta e organização.

O capítulo XXIII do Livro I de $\boldsymbol{O}$ Capital, "A Lei Geral da Acumulação Capitalista", é o capítulo central do processo de produção do capital. Sua estrutura, igualmente dialética, perfez, no seu âmbito, a mesma forma triádica do silogismo dialético - generalidade, particularidade, singularidade, que no caso se apresenta assim: generalidade - 1 . Não se alterando a composição do capital, a procura da Força de Trabalho aumenta com a acumulação; particularidade -2 e 3 . Decréscimo relativo de parte variável do capital com o progresso de acumulação e da concentração que a acompanha; produção progressiva de uma superpopulação relativa ou de um exército industrial de reserva; singularidade -4 e 5 . Formas de existência da superpopulação relativa. A lei geral da Acumulação Capitalista, Ilustração da Lei Geral da Acumulação Capitalista.

Eis, finalmente, a totalização conclusiva do processo de produção do capital, do capital em geral. Capital e força de trabalho estiveram frente a frente, a mais valia foi extraída e acumulada, a luta de classes se manifestou com confronto de complexos sociais contrapostos e inconciliáveis, a perspectiva concreta da transformação revolucionária do modo de produção: "Desintegrada a velha sociedade, de alto a baixo, por esse processo de transformação, convertidos os trabalhadores em proletários e suas condições de trabalho em capital, posto o modo capitalista de produção a andar com seus próprios pés, passa a desdobrar-se outra etapa em que prosseguem sob nova forma, a socialização do trabalho, a conversão do solo e de outros meios de produção em meios de produção coletivamente empregados, em comum, e, consequentemente, a expropriação dos proprietários particulares." (...) "Antes houve a expropriação da massa depois por pessoas

${ }^{31}$ MARX, 1968, op. cit. p. 880. 
usurpadoras, hoje, trata-se da expropriação de poucos usurpadores pela massa do povo." ${ }^{32}$.

Retome-se uma questão já mencionada antes. Marx ao final do Livro I de O Capital, apresenta como tendência, como caminho necessário do modo de produção capitalista, sua superação, seu aniquilamento, sua destruição como resultado da ação revolucionária da classe que se opõe ao capital, classe aqui tomada, como generalidade, como universalidade.

Com efeito, o Livro I de $\boldsymbol{O}$ Capital, perfez uma viagem completa, a produção do capital foi apresentada integralmente, e, no entanto, esta completude só realizou um primeiro conjunto de totalizações, a que pôs o capital como generalidade, como universalidade, infenso à ação do tempo, indiferente às intercorrências decorrentes da materialidade da mercadoria. Neste âmbito da exposição, o capital se apresenta como um todo homogêneo confrontado por um proletariado, também tomado sem efetiva diferenciação histórica concreta, por particularidades regionais, culturais, políticas. Enfim, o movimento da produção do capital o apreendeu em sua condição de capital em geral. O espetáculo, neste momento, ainda não revelou todos os seus conteúdos, só aqueles que resultam da pura objetividade das categorias, do que não pode deixar de se manifestar como essência abstrata, como universalidade imediata.

\section{Outras Viagens}

Não são poucos os que buscando valorizar a obra de Marx apresentam-na como uma sorte de monólito, perfeito, acabado, isento de ambiguidades e de equívocos. Esta imagem de uma obra perfeitamente realizada e que já disse tudo o que tinha a dizer, será contraditada neste texto, pela mobilização de uma outra imagem da obra de Marx, que experimentou transformações significativas ao longo de sua elaboração, transitando de uma versão tributária de um problemático eurocentrismo, de um progressocentrismo, de uma adesão acrítica à tese hegeliana dos "povos sem história", para compreensiva abertura, para a incorporação do internacionalismo, das especificidades da periferia do capitalismo, para a luta de classes como fenômeno histórico concreto.

Pedro Scaron estabeleceu uma periodização do pensamento de Marx e de Engels, sobre a questão nacional e sobre a realidade capitalista extraeuropeia, que vale a pena ser lembrada. Uma primeira etapa, diz Scaron, "tem data de início imprecisa, porém não posterior a 1847, e se encerra,

${ }^{32}$ Idem, p. 881-882. 
aproximadamente, com o término da Guerra da Criméia (1856). O característico deste período é que Marx e Engels combinam o repúdio moral às atrocidades do colonialismo com a mais ou menos velada justificação teórica do mesmo. Os famosos artigos sobre a dominação britânica na Índia enunciam, notavelmente, esta posição, resenhada assim pelo próprio Marx em uma carta de 14 de junho de 1853 a Engels: "Tenho prosseguido esta guerra oculta (a favor da centralização) um primeiro artigo sobre a Índia, no qual se apresenta como "revolucionária" a destruição da indústria vernácula pela Inglaterra. Isto resultou num "choque" (para os editores do The New York Daily Tribune, o periódico norte-americano no qual colaborava Marx)." (...)"A juízo de Marx e Engels o capitalismo desenvolvido de países como a Inglaterra exercia uma influência "civilizadora" (em certas ocasiões eles mesmos punham esta palavra entre aspas) sobre os "países bárbaros", ainda não capitalistas; os retiravam de sua inércia (uma inércia muito hegeliana, dito seja entre parênteses) para precipitá-los violentamente no caminho do progresso histórico." ${ }^{33}$.

Em 1856, diz Scaron, abriu-se uma nova etapa no pensamento de Marx e Engels sobre a questão nacional e colonial. Esta etapa iria até a fundação da AIT, em 1864, - Associação Internacional dos Trabalhadores, a chamada $\mathrm{I}^{\mathrm{a}}$ Internacional. "Trata-se de uma fase de transição. Marx e Engels não alteram, claramente, suas concepções teóricas sobre a relação entre as grandes potências europeias e o mundo colonial e semicolonial, porém, em seus escritos sobre o tema, o aspecto que prevalece, na maior parte dos casos, é a denúncia dos atropelos daquelas potências e a reivindicação dos direitos de chineses, indianos, etc., de resistirem aos agressores e ocupantes estrangeiros." ${ }^{\prime 3}$.

O terceiro período, iria de 1864 até a morte de Marx e 1883. "Se, desde certo ponto de vista, é exato que Marx é um dos principais fundadores da Internacional, não menos certo é que esta contribuiu, ainda que não para fundar, senão que para desenvolver o internacionalismo de Marx, libertando-o dos elementos contraditórios de seu internacionalismo. É notável, neste período, a mudança de posição de Marx com respeito à questão irlandesa." (...) "O livre cambista ("somente no sentido revolucionário") de 1848 a 1867, torna-se um lúcido expositor da necessidade de que países como a Irlanda se defendam da concorrência britânica, erguendo barreiras protetoras para suas incipientes indústrias. Não menos profunda foi a evolução do pensamento de Marx, com respeito à Índia." ${ }^{\prime 35}$.

\footnotetext{
${ }^{33}$ SCARON, Pedro. "A modo de Introducción" in MARX, Karl e ENGELS, Friedrich. Materiales para la Historia de América Latina, op. cit., 1974a, p. 6-7.

${ }^{34}$ Idem, p. 9.

${ }^{35}$ Idem, p. 9-10.
} 
A quarta etapa, vai da morte de Marx, 1883, à morte de Engels, 1895. Ainda que sob aspectos particulares tenha havido efetivos aperfeiçoamentos conceituais sobre o problema nacional, "em geral esta fase foi marcada por estagnação, quando não por involução conceitual." ${ }^{\prime 36}$.

Sobre o pensamento de Marx e Engels sobre a América Latina, disse Scaron - "Se ajusta a periodização anterior aos textos de Marx e Engels sobre América Latina? Em linhas gerais, sim, e particularmente no tocante às duas primeiras etapas. Os clássicos do marxismo passaram de um respaldo categórico e entusiasta à expansão norte-americana", (...) "entre 1847 e 1856, à crítica da mesma em período que vai, pouco mais ou menos, de 1856 a 1864. Em 1861, e anos seguintes, Marx se opõe resolutamente à intervenção anglo-franco-alemã no México", ainda que seus argumentos sejam muito pouco "marxistas", lembrando muito "o velho direito das gentes." ${ }^{37}$. Ainda mais significativo e problemático quanto à posição de Marx sobre a América Latina foi sua intransigente, incompreensiva e preconceituosa apreciação de Simon Bolivar ${ }^{38}$.

Com efeito, o que merece ser enfatizado nesse passo é que o pensamento de Marx se transformou ao longo do tempo, fruto do avanço de seus estudos, tendo particular influência sobre isso sua experiência como dirigente da Internacional e a obrigação de, nessa condição, ter que considerar a luta de classes em escala mundial em sua concreticidade.

O debate sobre o eurocentrismo de Marx e Engels não é recente. Contribuindo, efetivamente, para superar aspectos problemáticos do marxismo, alguns destes textos acabam por incorrer em equívocos importantes, a saber: 1) afirmaram um monolitismo da obra de Marx sobre a questão nacional e colonial; 2) afirmaram um eurocentrismo irremediável, presente na obra de Marx, que teria interditado qualquer possibilidade do pensamento de Marx de considerar, adequadamente, a realidade dos países periféricos; 3) se apresentaram como inauguradores da denúncia do eurocentrismo e do colonialismo do pensamento de Marx. Os equívocos listados aqui estão perfeitamente consignados em vários trabalhos de Edgardo Lander. Inicie-se pela análise de texto publicado em 2006 - "Marxismo, Eurocentrismo e Colonialismo" 39 , em que todos os três equívocos citados estão presentes. Não é particularmente rica a bibliografia citada pelo autor, no entanto, é significativo que dois dos principais autores que escreveram, criticamente, sobre a relação de Marx com a América Latina não sejam mencionados.

\footnotetext{
36 Idem, p. 13-14.

37 Idem, p. 15-16.

38 ARICÓ, José. Marx e a América Latina. Trad. port., Rio de Janeiro, Paz e Terra, 1982.

${ }^{39}$ LANDER, Edgardo. "Marxismo, Eurocentrismo e Colonialismo" in BORON, Atilio, AMADEO, Javier e GONZÁLEZ, Sabrina (Orgs.). A Teoria Marxista Hoje. Problemas e Perspectivas. Buenos Aires/São Paulo, CLACSO/Editora Expressão Popular, 2006.
} 
Tanto Pedro Scaron, quanto José Aricó, na década de 1970, já haviam iniciado importante e informada crítica sobre os elementos eurocentristas presentes em partes e em certo momento da obra de Marx. Assim, não há novidade em apontar os déficits e distorções analíticas tributárias do momento, raro no conjunto da obra de Marx, de importante incompreensão sobre temas como a questão nacional e colonial. A novidade, no caso, é a convicção peremptória de Edgardo Lander de que os equívocos de Marx sobre esses temas comprometem a sua obra como instrumento da emancipação de sociedades periféricas. Lander apoia-se em sua análise do eurocentrismo de Marx em três autores - Enrique Dussel, Anibal Quijano e Walter Mignolo - todos eles relevantes, que contribuem, efetivamente, para a crítica do eurocentrismo, da "colonialidade". A questão quanto a isso é que os três autores citados deram as suas contribuições a partir dos anos 1990, muito tempo depois que Scaron e Aricó, por exemplo, que escreveram nos anos 1970, tivessem realizado suas intervenções, que, mais antigas, continuam atuais por evitarem afirmar uma visão monolítica e fechada de Marx sobre a questão em tela. Trata-se, aqui, de questionar o juízo inapelável expresso nesta sentença: "o marxismo, a crítica mais radical à sociedade capitalista não escapa do eurocentrismo e do colonialismo característico dos saberes modernos hegemônicos." ${ }^{40}$. O problema básico dessa afirmativa não é a sua crítica ao marxismo, que para ser legítima terá que superar o reducionismo com que é apresentado, como visão à esquerda da modernidade europeia: “O marxismo é a síntese mais acabada tanto dos valores como das formas de conhecer dominantes no Ocidente dos últimos séculos." ${ }^{41}$. Lander reconhece a existência de várias fontes formativas do pensamento de Marx e as tensões decorrentes das várias apropriações dessas fontes. De todo modo, diz ele, "muitas das principais ideias-força sobre as quais se constrói o edifício teórico de Marx, as ideias mais significantes e apaixonantes do século XIX (progresso; ciência; desenvolvimento progressivo das forças produtivas; industrialismo; verdade e felicidade através da abundância) foram por água abaixo. Aquelas ideias que sintetizadas e articuladas constituíram os pilares de um assombroso edifício teórico, aquelas formações que constituíram a força fundamental dessa extraordinária obra da síntese, converteram-se hoje em seu contrário. O que ontem era fonte de força, é hoje fonte de debilidade." ${ }^{42}$.

Para sustentar esta visão sobre o pensamento de Marx é preciso transformá-lo numa peça inteiriça e homogênea uma sorte de cristal conceitual permanentemente idêntico a si mesmo em todos os seus momentos e partes. Ora, tal cristal não existe, mesmo que o seu próprio autor tenha acreditado na sua existência, por certo tempo. Acontece que esta face pe-

\footnotetext{
${ }^{40}$ Idem, p. 208.

${ }^{41}$ Idem, p. 210.

${ }^{42}$ Idem, p. 213-214.
} 
trificada foi superada pelo próprio Marx ao longo de sua obra. Diz Daniel Bensaid - "Marx costuma mostrar-se bastante admirado e respeitoso com os resultados das ciências positivas ou inglesas, para desprezá-las. Eles são um momento necessário do movimento de conhecimento, desde que não pare por aí." (...) "Ciência desconcertante, com efeito, a "ciência" de Marx. Numa busca prodigiosa do vivente, onde a ordem conceitual se desfaz sem interrupção na desordem carnal do combate, ela não para de misturar a sincronia e a diacronia, o universal da estrutura e a singularidade da história." ${ }^{43}$.

A questão que está sendo discutida aqui, em si já complexa, ganha ainda maior dificuldade porque não podemos evitar que apareça, recorrentemente, sobretudo para os que vivemos na periferia do capitalismo, herdeiros de uma experiência colonial, certa perplexidade diante do fato insofismável de momento eurocentrista de Marx, de filiação acrítica à tese dos "povos sem história", esquecendo-nos de que Marx, ao fazer isso estava ao par de seu tempo, sendo, de fato, mais notável e significativo que ele tenha sido capaz de superar esta perspectiva reducionista. Veja-se o que disse Theodor Shanin - "No último período de sua obra Marx deu um passo mais para uma conceptualização mais complexa e mais realista da heterogeneidade mundial das formas sociais, sua dinâmica e sua interdependência. A mudança na perspectiva de Marx deu-se como resultado de uma reflexão sobre $\boldsymbol{O}$ Capital, Livro I (publicado em 1867) e evidenciou a nova experiência e o testemunho dos anos 1870.

"Quatro acontecimentos aparecem como marcos no contexto político e intelectual do pensamento de Marx nesse período. Em primeiro lugar, a Comuna de Paris, em 1871, ofereceu uma dramática lição e um tipo de poder revolucionário não conhecido até então." (...) "Também aportou o crescendo final às atividades de Marx na primeira Internacional que terminou em 1872, para ser seguido de um período de reflexão. Em segundo lugar, durante os anos 1860 e 1870 se deu um fato fundamental dentro das Ciências Sociais: o descobrimento da pré-história, que "ampliaria a noção de tempo histórico em algumas dezenas de milhares de anos e que colocou as sociedades primitivas no círculo dos estudos históricos, combinando o estudo dos vestígios materiais com o da etnografia." (...) "Em terceiro lugar, e vinculado com os estudos sobre a pré-história, estava a ampliação do conhecimento sobre as sociedades rurais não capitalistas nos interstícios do mundo capitalista, especialmente tributários das obras de Maine, Firs e outros sobre a Índia. Por último, a Rússia, os russos ofereceram a Marx uma poderosa combinação do todo anterior: uma rica evidência em relação com as comunas rurais ("arcaicas", porém evidentemente vivas num mundo

${ }^{43}$ BENSAID, Daniel. Marx, O Intempestivo. Grandezas e misérias de uma aventura crítica (Séculos XIX e XX). Trad. port., Rio de Janeiro, Civilização Brasileira, 1999, p. 288, 284. 
de hegemonia capitalista) e com a experiência revolucionária direta, junto com a teoria e a prática do populismo revolucionário russo." ${ }^{44}$.

Refletindo sobre este mesmo tema, as mudanças de perspectiva do pensamento de Marx, sua superação do eurocentrismo, José Aricó estabeleceu um quadro sintético baseado em sete questões básicas:

1) rechaço da tentativa de transformar a teoria de Marx sobre a gênese do capitalismo na Europa Ocidental em uma teoria histórico-filosófica geral;

2) reconhecimento do caráter desigual e contraditório do desenvolvimento econômico do mundo ocidental e não ocidental e interdependência conflitiva das mesmas. Reconhecimento, portanto, da subordinação do processo de acumulação dos excedentes dos países não europeus com relação aos europeus e do caráter colonial de vínculo político entre eles;

3) previsão do deslocamento do centro do processo revolucionário do mundo ocidental ao mundo não ocidental e constituição da revolução nacional dos países dependentes condicionada à revolução social dos países europeus;

4) exame da possibilidade histórica da passagem das sociedades não capitalistas ao socialismo sem a necessária passagem pelo estágio capitalista;

5) identificação, especialmente para o caso da Rússia, de instituições comunitárias camponesas com eixo de passagem de sociedades não capitalistas a socialistas;

6) percepção dos diferentes sujeitos históricos do movimento revolucionário nas sociedades asiáticas e/ou coloniais (campesinato, intelectuais, pequena burguesia, classe operária embrionária) em comparação com aquelas das sociedades europeias e capitalistas;

7) afirmação da natureza distinta das tarefas necessárias à transformação das sociedades asiáticas e/ou coloniais (independência política, revolução agrária, proteção industrial e comercial) em comparação com aquelas a serem realizadas em sociedades europeias e capitalistas" ${ }^{45}$

A relação de Marx com a Rússia é exemplar do movimento de seu pensamento, das transformações que experimentou de uma rotunda incompreensão das realidades estranhas à Europa Ocidental, à igualmente forte descoberta das possibilidades emancipatórias de uma sociedade com tão fundas raízes comunitárias como a Rússia. "Ao final da década (1860), Marx se deu conta, cada vez mais, de que, ao lado da Rússia oficial, a qual ele havia atacado com tanta frequência como centro e guardiã da reação europeia, havia surgido uma Rússia diferente de aliados revolucionários e de estudiosos

${ }^{44}$ SHANIN, Theodor. El Marx Tardio y la Via Rusa. Op. cit., 1990, p. 18-19.

${ }^{45}$ FRANCO, Carlos. «Apresentação» a ARICÓ, José. Marx e a América Latina, op. cit. p. 22-23. 
radicais, crescentemente comprometidos com seu próprio trabalho teórico. A primeira tradução de $\boldsymbol{O}$ Capital foi para o russo, uma década antes que viesse à luz a tradução para o inglês. Da Rússia vinham, também, notícias mais auspiciosas, que sobressaíam ainda mais pelas esperanças que reacendiam revolucionárias na Europa Ocidental depois da Comuna de Paris.

“Em 1870-1871, Marx estudou de forma autodidata o russo, com o objetivo de aproximar-se diretamente aos fatos e do debate publicado nessa língua." (...) "Marx procedeu com similar vigor a estudar as fontes russas e, efetivamente, converteu os livros dos intelectuais radicais russos em livros de texto para aprender o idioma, começando com Herzen e prestando particular atenção a Flerovski e Tchernichevsky." ${ }^{\prime 6}$.

Marx, mais de uma vez, manifestou seu interesse pela obra de Tchernichevsky, um dos grandes nomes do chamado "populismo russo". Ainda mais forte foi sua relação com Nicolai Frantsevich Danielson, chamado Nicolai-on, primeiro tradutor de $\boldsymbol{O}$ Capital: “Na década de 1870 e 1880 ele foi considerado como o maior expoente do marxismo na Rússia. Manteve uma vasta correspondência com Marx, que instou a Danielson a escrever Linhas Gerais sobre nossa Economia posterior à Reforma (como artigo em 1880 e que saiu com livro em 1893). Danielson acreditava que a socialização do trabalho podia acontecer sem passar pela fase capitalista do desenvolvimento, se o Estado levasse adiante a unificação da agricultura e da indústria. Plekhanov elegeu Danielson como alvo de seus ataques em Nossas Diferenças (1884), como fará mais tarde Lênin em O Desenvolvimento do Capitalismo na Rússia (1899)." ${ }^{47}$.

O fato importante a ser registrado é que Marx e o marxismo chegaram à Rússia pelas mãos dos populistas. Foram os teóricos e militantes populistas, foram as organizações políticas populistas, que projetaram o marxismo na Rússia. Que, mais tarde, os bolcheviques tenham feito do ataque aos populistas um dos pontos centrais de sua luta política, é fato que tem pelo menos dois aspectos que merecem destaque: 1) de um lado o ataque encarniçado dos bolcheviques aos populistas traduziu a necessidade tática de corrente então minoritária, os bolcheviques, de disputar a hegemonia do processo revolucionário russo com corrente majoritária e enraizada, o populismo; 2) de outro lado, a separação radical que se estabeleceu entre bolcheviques e populistas, para não falar da exclusão de outras correntes revolucionárias, como os anarquistas e os mencheviques de esquerda, ou seja, a afirmação de exclusivismo bolchevique significou a adoção de um caminho revolucionário que não só não era o único possível, como também excluiu a participação da rica e diversa contribuição das outras correntes revolucionárias da Rússia, de então. No caso específico dos populistas, a

${ }^{46}$ SHANIN, 1990, op. cit. p. 19-20.

${ }^{47}$ SANDERS, Jonathan. "La escena rusa: Nota biográfica" in SHANIN, Theodor. El Marx Tardio y la Via Rusa. Op. cit., 1990, p. 220-221. 
interdição dos bolcheviques significou privar o processo revolucionário russo não só de uma relevante experiência popular, quanto de sua particular sensibilidade para lidar com as questões da agricultura e da natureza, em grande medida sintonizados com o mais avançado das perspectivas contemporâneas sobre ecologia e meio ambiente.

O fato é que Marx foi um permanente interlocutor dos populistas, e considerava com particular interesse o desenvolvimento da propriedade comunal russa - "Sobre a base desta premissa teórica, Tchernichevsky pensava que, dado o desenvolvimento do Ocidente avançado, seria possível que a Rússia saltasse diretamente da propriedade comunal da terra para o socialismo." (...) "Marx ficou profundamente impressionado por estas ideias. Em minha opinião, Marx chegou tão longe quanto para considerá-las racionais e também conceber como possível que dada a existência do Ocidente avançado como uma pré-condição, a Rússia poderia partir de sua comuna camponesa e passar, imediatamente, ao socialismo." ${ }^{48}$. É este o contexto teórico no qual, em 1881 Marx responde à indagação de Vera Zasulich: "A análise de $\boldsymbol{O}$ Capital, portanto, não aporta razões nem a favor, nem contra a vitalidade da comuna russa. Entretanto, o estudo especial que tenho feito sobre ela, que inclui a busca do material original, convenceu-me de que a comuna é o ponto de apoio para regeneração social da Rússia. Porém, para que possa funcionar como tal, as influências daninhas que a assaltam por todos os lados devem ser primeiro eliminadas e logo se lhe devem garantir as condições normais para seu desenvolvimento espontâneo." ${ }^{49}$.

Sabe-se que o Livro III de $O$ Capital é aproximação ao concreto, ao mundo dos "vários capitais", da singularidade do movimento do capital. Sabe-se, também, que ficou inconcluso, e que mesmo que tivesse sido incluído, no limite do que poderia avançar, a realização plena da crítica da economia política, isto é, a realização do capital como totalidade concreta e complexa, não poderia ser inteiramente posta porque carecendo, ainda, que fossem postos: o Estado, o comércio externo e o mercado mundial e as crises, isto é, as condições da possibilidade para a realização da concorrência, o pleno funcionamento do mundo dos vários capitais. É a luz disso que ganha particular relevo a intenção de Marx "de utilizar a Rússia para o volume III de $\boldsymbol{O}$ Capital, tal como havia utilizado a Inglaterra no volume I." ${ }^{50}$. Isto é, a periferia do capitalismo, suas singularidades históricas e estruturais como componentes indispensáveis para se pensar o movimento concreto do capital em sua totalidade.

\footnotetext{
${ }^{48}$ WADA, Haruki. "Marx y le Rusia revolucionaria" in SHANIN, Theodor. El Marx Tardio y La via Rusa, op. cit., 1990, p. 69-70.

${ }^{49}$ MARX, Karl. "La Respuesta a Zasulich" in SHANIN, Theodor. El Marx Tardio y la Via Rusa. Marx y la periferia del capitalismo. Trad. esp., Madrid, Editorial Revolución, 1990 (org.), p. 162. ${ }^{50}$ SHANIN, op. cit. p. 9.
} 
A inequívoca superação por Marx, de seu momento eurocentrista, não teria sido completa, para alguns autores. Carlos Franco, por exemplo, analisando a posição de Marx sobre a América Latina diz que Marx foi apenas parcialmente capaz de superar o eurocentrismo. Ele mudou de posição com relação à Rússia, à Índia, à China, à Irlanda, à Turquia, por exemplo, mas teria mantido uma incompreensão, isto é, um preconceito básico com relação à América Latina. As razões para isso, para Carlos Franco, seriam de ordem psicológica: "em última análise, a ambiguidade latino-americana (campo popular multiétnico, elites estranhas ao corpo popular, baixa densidade nacional, estados artificiais, crises de poder, etc.) submetia a tensão à capacidade da reorientação do pensamento marxiano, sua disposição para recolocar sua teoria em um campo problemático original. E é aqui onde Marx revela aquilo que os psicólogos denominam "intolerância ao ambíguo", que constitui uma espécie de horror àquilo que desafia e questiona todas as coordenadas sobre as quais levantamos nossa compreensão do real.." ${ }^{51}$ Com efeito, a tese de Carlos Franco sobre "as falhas do enfoque marxiano sobre a América Latina", parece correta, em termos gerais. Por outro lado, não é possível acompanhá-lo em algumas de suas principais implicações: não faz sentido, como quer Franco, dizer que Marx "evitou a problemática latino-americana". ${ }^{52}$ De fato, ele se debruçou sobre o tema em vários momentos. $\mathrm{O}$ conjunto destas intervenções está reunido num volume organizado por Pedro Scaron, com cerca de 350 páginas ${ }^{53}$. É possível que Franco considere 350 páginas como tratamento insuficiente de uma realidade complexa como a da América Latina, do mesmo modo, então, terão que ser classificados como insuficientes os tratamentos que Marx e Engels deram, por exemplo, à Espanha (293 páginas), à Irlanda (390 páginas), e à questão nacional e à formação dos Estados (268 páginas) ${ }^{54}$. Nos três casos os temas exigiam ter maiores cuidados. Contudo, é um equívoco dizer que Marx evitou esses temas, sendo ainda mais problemática a afirmativa de Franco sobre a existência de um "definitivo desencontro da América Latina com o marxismo" - "uma espécie de mútua e secreta repulsão, que afastaria a América Latina do marxismo (isto é, a realidade da teoria) e expulsaria o marxismo da América Latina (isto é, a teoria, da realidade)." ${ }^{55}$ Não há propósito em repetir a decisiva análise de José Aricó já reportada aqui.

${ }^{51}$ FRANCO, Carlos, op. cit. p. 25-26.

${ }^{52}$ Idem, p. 27.

${ }^{53}$ MARX, Karl e ENGELS, Friedrich. Materiales para la Historia da América Latina. Trad. esp., Córdoba, Cuadernos Pasado y Presente, n. 30, 1974a.

${ }^{54}$ MARX, Karl, ENGELS, Friedrich. Imperio y Colonia. Escritos sobre Irlanda. Trad. esp., México, Cuadernos Pasado y Presente, n. 72, 1979. MARX, Karl, ENGELS, Friedrich. La Cuestión Nacional y la formación de los Estados, Trad. esp., México, Cuadernos Pasado y Presente, n. 69, 1980. MARX, Karl, ENGELS, Friedrich. La Revolución en España. Trad. esp., Moscou, Editorial Progreso, 1980a.

${ }^{55}$ FRANCO, Carlos, op. cit. p. 11. 
Com efeito, Marx, em vários momentos de sua obra, sobretudo em sua produção jornalística, considerou a realidade da América Latina a partir de posições que transitaram de funda incompreensão até momento mais compreensivo e equilibrado. A América Latina não foi a única região sobre a qual Marx se equivocou antes de superar os equívocos e preconceitos iniciais. O que parece escapar a Franco é que mesmo que Marx não tivesse falhado em suas análises sobre a América Latina, como sobre outras realidades periféricas, ainda assim, sua análise sobre essas realidades estaria sempre aquém do necessário à apreensão de suas especificidades históricas, permanecendo como realidades apreendidas abstratamente, em que as determinações capazes de dar vida aos conceitos podem estar apenas pressupostas. Com efeito, a tarefa de transitar da generalidade para a singularidade, de estabelecer um conjunto de mediações capazes de arrancar o conceito de sua conformidade consigo mesmo e realizá-lo como concreto pensado, é tarefa a que se propuseram José Carlos Mariátegui, em seu 7 Ensaios sobre a Realidade Peruana (1928) e Lênin com o seu Desenvolvimento do Capitalismo na Rússia (1899), que provam a capacidade do marxismo de se apropriar de realidades históricas estranhas à Europa Ocidental. Com efeito, a frase de Marx, que está no prefácio da primeira edição do Livro I de O Capital, de 1867, "A sede clássica desse modo de produção é, até hoje, a Inglaterra" (interrompa-se a citação para dizer que Marx admite que poderia haver outra "sede clássica" do modo de produção capitalista, e de fato houve, os Estados Unidos)." É este o motivo pelo qual, ao desenvolver minha teoria, servi-me deste país como principal ponto de exemplos" (novamente interrompo a citação para sublinhar a palavra exemplos). "Porém, se o leitor alemão farisaicamente, encolher os ombros ante a situação dos trabalhadores industriais ou agrícolas ingleses, ou se se consolar com a ideia otimista de que na Alemanha as crises estão longe de haverem se deteriorado tanto, ver-me-ia obrigado a adverti-lo: "De te fabula narratur" ("A história é sobre ti") ${ }^{56}$ - não deve ser entendida como uma espécie de condenação histórica, esquema linear e rígido de etapas, a que todos os países estariam sujeitos. É de todo essencial, aqui, que se reconheça que o conceito de história que importa destacar é, em tudo, distante de uma teleologia, onde tudo caminha para um fim já previsto, seja, exatamente, pela centralidade da luta de classes, que faz com que o futuro esteja em aberto, sujeito a surpresas, ao inaprisionável da imaginação humana.

Assim, a frase latina citada por Marx só faz sentido como descrição geral, abstrata, das tendências do desenvolvimento capitalista: "Acumulação de riqueza num polo é ao mesmo tempo acumulação de miséria, de trabalho atormentante, de escravatura, ignorância, brutalização e degradação moral, no polo oposto, constituído pela classe cujo produto vira capital." (...)

${ }^{56}$ MARX, 1977a, op. cit. p. 6-7. 
"Infere-se daí que, na medida em que se acumula o capital, tem de piorar a situação do trabalhador, suba ou desça sua remuneração." ${ }^{57}$.

É ocioso destacar o significado da expressão "suba ou desça sua remuneração" como prova de que Marx admitiu, no momento mesmo em que apresentava a "lei geral da acumulação capitalista", que não há tendência à pauperização absoluta em sua visão estratégica, que os salários podem subir, que, ainda assim, a situação dos trabalhadores tende a piorar seja porque há permanente aprofundamento da alienação do trabalho, seja porque há maior concentração e centralização do capital, e, na mesma medida em que aumenta o exército industrial de reserva. De novo, é ocioso insistir o quanto esses processos estão exuberantemente presentes na contemporaneidade.

Cada país, cada sociedade concreta vive as manifestações do domínio do capital à sua maneira, num processo em que as forças gerais do capital não atuam no vácuo, num espaço indiferenciado, mas devem interagir num meio histórico, social e natural concreto, de que resultam tanto obstáculos, resistências, fricções, como oportunidades e vantagens.

De todo modo, o que é preciso ser dito, para concluir a discussão proposta por Carlos Franco é que Marx, no âmbito do Livro I de $\boldsymbol{O}$ Capital, e mesmo nos livros II e III, não poderia dar tratamento detalhado à América Latina, nem a qualquer outra realidade periférica, como exigência do método de exposição de $\boldsymbol{O}$ Capital.

Sabe-se que Marx se preparou para fazer da Rússia, de um país periférico, campo privilegiado da investigação empírica do Livro III, como aproximação da exposição dos "vários capitais". Trabalhou até o final de sua vida em acumular informações sobre a Rússia, sem que tenha considerado suficiente o que acumulara. Tendo informações muito menos detalhadas sobre a América Latina, e ainda preso à certos resquícios eurocentristas, a posição de Marx sobre o tema não avançou tanto quanto no caso da Rússia. De todo modo, não há porque considerar o pensamento marxista, a crítica da economia política como projeto em construção, aberto e emancipatório, como capaz de apreender a realidade latino-americana.

\section{Qual é mesmo o nome do País?}

Os estudos de marxologia têm recebido importantes aportes, nos últimos tempos, junto a contribuições relevantes como as de Maximilien Rubel, Roman Rosdolsky, Ernest Mandel, Pedro Scaron, José Aricó, Enrique Dussel, Rolf Hecker, Michael Heinrich, Michael Krätke, Carl Erich Vollgraf, Regina Roth, Susumu Takenaga, Fred Moseley, Roberto Fineschi, entre

${ }^{57}$ MARX, 1968, op. cit. p. 748-747. 
outros nomes significativos. Os efetivos avanços na compreensão da obra de Marx, de sua complexa escritura, que têm sido alcançados decorrentes dos trabalhos elaborados a partir da MEGA, não evitam a continuidade de certas polêmicas e mesmo a instauração de novas polêmicas. Duas dessas polêmicas serão retomadas aqui: a primeira, se Marx teria abandonado, ou não, o plano de elaborar a crítica da economia política em 6 livros, substituindo essa primeira ideia, presente já em 1857, pela redação de $\boldsymbol{O}$ Capital, com o subtítulo Crítica da Economia Política, em 4 livros; e uma segunda polêmica, desdobramento da primeira, que defende a ideia de que Marx teria abandonado a estrutura de exposição de $\boldsymbol{O}$ Capital, que num primeiro momento constaria da apresentação do capital em geral, a partir do conteúdo dos livros I e II de $\boldsymbol{O}$ Capital, reservando-se para o livro III a emergência dos "vários capitais", da "concorrência".

Esse gênero de polêmica não parece poder ser resolvido com provas textuais, ou testemunhais, definitivas. Afinal, trata-se de um projeto formulado em 1857, modificado em 1865/66, e que ao longo da vida de Marx experimentou variantes-adaptações. Roman Rosdolsky, que enfrentou a questão das modificações dos planos de estruturação da crítica da Economia Política, oferece uma convincente abordagem da questão que poderia ser resumida assim: 1) Marx teria modificado o plano de 1857, o dos seis livros da crítica da economia política, em 1865/66, pela incorporação, ao Livro I, das temáticas que deveriam constar dos livros sobre propriedade da terra e sobre o trabalho assalariado; 2) por outro lado, os livros sobre o Estado, o Comércio Exterior e o Mercado Mundial e as Crises não foram abandonados senão que "eles estavam destinados a um desdobramento da obra." 58 , o que acabou não ocorrendo, o que não impede que isso possa ser feito, ou necessite ser feito, confirmando com isso, que, na verdade, ainda que Marx tivesse elaborado aqueles três livros, eles não esgotariam a necessidade de que, a cada momento, reconhecendo as transformações estruturais do capital, as novas formas concretas com que se apresentam a necessidade de processo histórico, seja atualizada a análise do Estado, do comércio externo, do mercado mundial e das crises; 3) Rosdolsky defende, enfaticamente, que Marx manteve a estrutura expositiva do capital como tendo dois momentos necessariamente articulados: a exposição do capital em geral, pré-condição para que pudesse ser posta a pluralidade de capitais, os vários capitais. Para Rosdolsky, essa estrutura, explicitamente, apresentada nos Grundrisse, não foi abandonada quando da redação de $\boldsymbol{O}$ Capital. Diz Rosdolsky: "Assim como os Grundrisse, o primeiro e o segundo tomo de $\boldsymbol{O}$ Capital limitam-se apenas, em última análise, a "enfocar abstratamente, uma forma pura, o fenômeno da formação do capital" e analisar o processo de circulação e reprodução em sua forma fundamental, reduzido à sua expressão mais abstrata", ou seja,

${ }^{58}$ ROSDOLSKY, Roman. Gênese e Estrutura de O Capital de Karl Marx. Trad. port., Rio de Janeiro, EDUERJ/Contraponto, 2001, p. 58. 
a considerar o capital em geral". (Daí, também, a hipótese geral de que as mercadorias são vendidas por seus valores) A diferença metodológica propriamente dita só começa no terceiro tomo. Embora os Grundrisse também tratem, em sua última seção, do lucro, da taxa geral do lucro e da queda tendencial desta taxa, o enfoque permanece centrado no "lucro em geral", no "lucro da classe capitalista", e não no lucro de "um capital individual em detrimento de outro"." 59 .

Michael Heinrich, um dos nomes mais significativos entre os especialistas sobre o pensamento de Marx a partir da MEGA, contestou a posição de Rosdolsky em pelo menos dois aspectos importantes: 1) ele sustenta que Marx abandonou o plano dos seis livros, pelo menos desde $1862^{60} ; 2$ ), e ele defende que Marx teria modificado sua proposta metodológica, entre 1859 e 1867, ao constatar a impossibilidade de expor, rigorosamente, o capital em geral, isto é, suas invasões espúrias de características típicas do âmbito dos vários capitais ${ }^{61}$.

Heinrich diz - "No fim de 1862, Marx decidiu substituir seu projeto de uma crítica da economia política em seis livros (anunciado em 1859, no prefácio do primeiro caderno) pela elaboração de uma nova obra: $\mathbf{O} \mathbf{C a}$ pital." ${ }^{62}$. Como prova de seu argumento cita carta de Marx a Kugelmann, de 28 de dezembro de 1862. Ora, esta carta, não autoriza a interpretação de Heinrich. Eis o que escreve Marx: "Alegrei-me muito ao comprovar, ao ler sua carta, que tanto tu, quanto teus amigos, se interessaram carinhosamente pela minha "Crítica da economia política". A segunda parte está já finalmente terminada, isto é, resta passá-la a limpo e lhe dar o último retoque com vistas à impressão. Terá mais ou menos 30 folhas de impressão. É a continuação do fascículo I, porém a obra aparecerá, em separado, com o título de $\boldsymbol{O}$ Capital, e "Contribuição à crítica da economia política" não aparecerá senão como subtítulo. De fato, a obra não compreende mais do que o que deveria constituir o terceiro capítulo da primeira parte: "O capital em geral". Não se inclui, pois, nem a concorrência dos capitais, nem o crédito. Este volume compreende o que os ingleses chamam de "The Principles of Political Economy". É (junto com a primeira parte) a quintessência, e o desenvolvimento do que vem em continuação e poderiam realizá-lo outros sobre a base do que já está escrito." ${ }^{63}$.

Com base nesta carta, parece excessivo concluir-se que Marx abandonou o projeto dos seis livros, senão que disse, que com base no já escrito, ou-

\footnotetext{
${ }^{59}$ Idem, p. 56.

${ }^{60}$ HEINRICH, Michael. "Prefácio - O Livro II de O Capital" in MARX, Karl. O Capital, Livro II, Trad. port., São Paulo, Boitempo Editorial, 2014, p. 18-19.

${ }^{61}$ BURKETT, op. cit. p. 50.

${ }^{62}$ HEINRICH, op. cit. p. 18-19.

${ }^{63}$ MARX, Karl e ENGELS, Friedrich. Cartas sobre "El Capital". Trad. esp., Barcelona, Editorial Laia, 1974, p. 102.
} 
tros seriam capazes de escrever o que faltava. É possível que Marx tenha subestimado, e muito, as dificuldades, o quanto de pesquisa e esforço isso demandaria. De todo modo, não só ele não abandonou o projeto dos seis livros, como não excluiu a possibilidade de ele mesmo retomar a tarefa.

Michael Krätke concorda parcialmente com Heinrich ao afirmar que Marx modificou a estrutura da obra, "abandonando a dicotomia hegeliana do capitalismo geral versus os capitais individuais, como princípio da organização da obra"; mas diverge dele ao dizer que "Marx nunca renunciou totalmente ao plano dos seis livros" ${ }^{\prime \prime 4}$.

Insista-se ainda, um pouco mais, na discussão sobre o quanto é difícil resolver polêmicas como as que estão em pauta, sobretudo sobre uma obra vasta e inconclusa, isto é, questões de ordem metodológica, que não se restringem a detalhes ou aspectos factuais, recorrendo-se a uma ou outra evidência textual. Veja-se a questão da Introdução aos Grundrisse, escrita em 1857, considerada, com razão, como uma tentativa de apresentação da metodologia da crítica da economia política. Em 1859, diz Marx - “Suprimo uma introdução geral que havia esboçado, pois, graças a uma reflexão mais atenta, parece-me que toda antecipação perturbaria os resultados ainda a comprovar e o leitor que se dispuser a seguir-me terá que se decidir a ascender do particular para o geral.". ${ }^{65}$

Aparentemente a questão estaria resolvida, o próprio autor, Marx, se pronunciou sobre o assunto, em 1859. Acontece, que Marx viveu ainda muito mais tempo, e neste tempo muito modificou, aperfeiçoou, pesquisou, aprendeu. Assim, o que foi tido por suprimido em 1859, voltou a aparecer em anotações de Marx em 1863, quando mencionou a necessidade de introdução metodológica ${ }^{66}$.

Com efeito, o que efetivamente está na base da polêmica que coloca a interpretação de Rosdolsky em questão, que agrega autores como Krätke e Heinrich, é que eles entendem necessário expurgar a obra de Marx de seus "excessos dialéticos hegelianos", enfatizando a sua dimensão "científica". Diz Krätke: "Temos, portanto, quatro ou cinco versões diferentes da crítica da economia política de Marx." (...) "Entre essas diferentes versões não há uma ruptura nítida." (...) "As observações autocríticas mais radicais encontram-se no manuscrito de 1857-58. Nesse manuscrito, ao tentar apresentar o sistema das categorias econômicas de uma maneira "dialética", Marx se depara com os limites próprios do método dialético e alcança um modo de exposição sistemática que lhe parece adequado para

\footnotetext{
${ }^{64}$ KRÄTKE, op. cit. p. 16.

${ }^{65}$ MARX, Karl. Para a Crítica da Economia Política. Trad. port., São Paulo, Abril Cultural. Karl Marx, 1974a, p. 134.

${ }^{66}$ ROSDOLSKY, op. cit. p. 481.
} 
os requisitos de uma Ciência Social, histórica e política, como a economia política. Ele retoma e leva mais adiante sua crítica a Hegel e do maneirismo hegeliano, afastando-se cada vez mais de uma dialética incondicional. Chega finalmente a uma dialética muito reduzida e comedida, o que ele não considera como um deslizamento em direção a uma popularização nem a uma vulgarização de sua teoria." ${ }^{\prime \prime 7}$.

Essa reserva com relação à dialética na obra de Marx não é fenômeno recente. Antes de Krätke, houve correntes e autores - os austromarxistas, os discípulos de Galvano Della Volpe, Althusser e seus colaboradores - que contestaram a influência hegeliana sobre Marx, buscando em Kant, por exemplo, um antídoto contra a dialética hegeliana e suas contaminações metafísicas e anticientíficas.

Esta questão, a dos ganhos de "cientificidade" da obra de Marx pelo abandono de Hegel, aparece, exemplarmente, na versão francesa de $\boldsymbol{O} \mathbf{C a}$ pital, em que Joseph Roy, com a concordância de Marx, introduziu várias modificações no texto visando eliminar certas "complicações filosóficas desnecessárias": "A intenção de pôr o texto ao nível filosófico do leitor francês - nível que Marx não supunha particularmente alto - se deve, sem dúvida alguma, à poda de muitas das passagens em que era mais patente a influência de Hegel sobre o autor de $O$ Capital". (...) O resultado é uma edição, a francesa, que se em alguns momentos tem passagens que superam a versão alemã, no geral, padece de graves defeitos que recomendariam uma outra tradução para o francês. Diz Pedro Scaron - "Não se sustentam mais razões legítimas, que as afetivas, para que se continue editando, em vez de uma tradução científica do livro, a defeituosa versão de Roy. Ali pesquisadores como Althusser - cujas teses anti-hegelianas se beneficiam diretamente, por assim dizer, da desehegelianação do texto francês - recomendam - "aos que possam fazê-lo - a leitura do "texto alemão"."

Os adversários da presença de Hegel na obra de Marx acentuam dois temas: de um lado, entendem que a dialética seria incompatível com um tratamento especificamente científico da realidade; e de outro lado, também vêm incompatibilidade entre a necessidade do enriquecimento empírico da pesquisa, da crítica da economia política, e o modo dialético de exposição da matéria apreendida no âmbito da empiria, da pesquisa. Se a primeira objeção à dialética pode ter alguma sustentação racional, pela atribuição de incontornável vício metafísico à dialética, mesmo a marxiana, a segunda opção tem algo de gratuita. Afinal, por que a mobilização da empiria, dos fatos, dos eventos, da análise concreta, quantitativa, factual, documental, estatística, da legislação, etc., seria incompatível com a exposição dialética e, ainda mais grave, seria incompatível com a produção do conheci-

${ }^{67}$ KRÄTKE, op. cit. pp. 15-16.

${ }^{68}$ SCARON, 1977a, op. cit. p. XXXVII. 
mento? Krätke está convencido de que se Marx, ao final de sua vida, ou seja, depois de ter produzido a obra que conhecemos dele, tivesse tido tempo para retomar $\boldsymbol{O}$ Capital e reescrevê-lo, inteiramente, esta versão acabada do livro - "teria se tornado um livro ainda mais rico que aquele que conhecemos. Teria comportado muito menos "leis gerais" e muito mais reservas no que se refere à sua validade." (...) "Certamente, Marx não teria renunciado a seu método "genético" de "desenvolvimento" das categorias. Porém, durante o trabalho realizado ao longo de seus quinze últimos anos, ele não perdeu uma só oportunidade de perceber cada vez mais claramente os "limites do método dialético"69.

Concorde-se com Krätke sobre a importância que teria, para a plena realização de $\boldsymbol{O}$ Capital, o seu enriquecimento empírico, factual. Por outro lado, não há razão para aceitar a tese de que a presença da dialética foi um estorvo, uma inconveniência, que comprometeu a elaboração integral da crítica da economia política, a não ser como fruto de idiossincrasia ou de preconceito.

Em sentido oposto, sustenta-se aqui que se é possível falar de ciência, legitimamente, no campo do marxismo ela terá de ser compatível com dialética tal como Marx dela se apropriou.

Mas, há ainda, um outro aspecto a ser considerado quando se estabelece esta disjuntiva entre um marxismo com e um marxismo, sem dialética. Considerem-se as implicações teóricas, filosóficas, políticas, ideológicas decorrentes das várias versões de $\boldsymbol{O}$ Capital e suas traduções. Tome-se como exemplo, particularmente sensível, as várias formas como uma única, e importante expressão, do Livro I de $\boldsymbol{O}$ Capital foi traduzida para o francês, espanhol, inglês, português, italiano. A expressão em tela encontra-se no item 4 do capítulo I, da $2^{\underline{a}}$ edição alemã de $\boldsymbol{O}$ Capital, chamado: "o caráter fetichista da mercadoria e seu segredo" ${ }^{\prime 70}$.

O que se quer mostrar é que esta expressão foi traduzida de várias maneiras, atendendo tanto a competência e experiência dos tradutores, mas, sobretudo, às suas escolhas filosóficas. $\mathrm{O}$ trecho em que a expressão aparece é o seguinte, na tradução de Pedro Scaron - "A primera vista, una mercancia parece ser una cosa trivial, de comprensión inmediata. $\mathrm{Su}$ análisis demuestra que es un objeto endemoniado, rico en sutilezas metafísicas y reticencias teológicas." ${ }^{\prime 71}$. A expressão que se quer destacar é "objeto endemoniado". Para tanto vamos apresentar um quadro que lista as traduções desta expressão para o francês, inglês, espanhol, português e italiano.

\footnotetext{
${ }^{69}$ KRÄTKE, op. cit. p. 27.

${ }^{70}$ MARX, 1977a, op. cit. p. 87-102.

${ }^{71}$ Idem, p. 87.
} 
Traduções da expressão "objeto endemoniado" que consta do capítulo I, do Livro I, de O Capital

\begin{tabular}{|c|c|c|c|c|}
\hline Idioma & Tradutor & Edição & Data & Tradução \\
\hline Francês & J. Roy & $\begin{array}{c}1^{a} \text { edição em } \\
\text { Francês } \\
\text { 1872/75 }\end{array}$ & $1872 / 75$ & $\begin{array}{l}\text { "chose très } \\
\text { complexe" }\end{array}$ \\
\hline Inglês & $\begin{array}{c}\text { Samuel Moore e } \\
\text { Edward Aveling }\end{array}$ & $\begin{array}{c}3^{\mathrm{a}} \text { edição } \\
\text { alemã }-1883\end{array}$ & 1886 & "very queer thing" \\
\hline Castelhano & Juan B. Justo & $\begin{array}{c}4^{\mathrm{a}} \text { edição } \\
\text { alemão }-1890\end{array}$ & 1898 & "cosa endiablada" \\
\hline Castelhano & Manuel Pedroso & $\begin{array}{c}4^{\mathrm{a}} \text { edição } \\
\text { alemã- } 1890\end{array}$ & 1931 & $\begin{array}{l}\text { "cosa muy } \\
\text { truculenta" }\end{array}$ \\
\hline Castelhano & $\begin{array}{c}\text { Wenceslau } \\
\text { Roces }\end{array}$ & $\begin{array}{c}4^{\mathrm{a}} \text { edição } \\
\text { alemã }-1890\end{array}$ & $1935 / 46$ & $\begin{array}{l}\text { "objetos muy } \\
\text { intrincados" }\end{array}$ \\
\hline Português & $\begin{array}{l}\text { Reginaldo } \\
\text { Sant'Anna }\end{array}$ & $\begin{array}{c}4^{\mathrm{a}} \text { edição } \\
\text { alemã - } 1890\end{array}$ & 1968 & $\begin{array}{l}\text { "algo muito } \\
\text { estranho" }\end{array}$ \\
\hline Castelhano & P. Scaron & $\begin{array}{c}2^{\mathrm{a}} \text { edição } \\
\text { alemã }-1873\end{array}$ & 1975 & $\begin{array}{c}\text { "objeto } \\
\text { endemoniado" }\end{array}$ \\
\hline Português & $\begin{array}{c}\text { Régis Barbosa e } \\
\text { Flávio Kothe }\end{array}$ & $\begin{array}{c}4^{\mathrm{a}} \text { edição } \\
\text { alemã — } 1890\end{array}$ & 1983 & $\begin{array}{l}\text { "coisa muito } \\
\text { complicada" }\end{array}$ \\
\hline Italiano & $\begin{array}{l}\text { Roberto } \\
\text { Fineschi }\end{array}$ & $\begin{array}{c}4^{\mathrm{a}} \text { edição } \\
\text { alemã }-1890\end{array}$ & 2008 & $\begin{array}{c}\text { "cosa } \\
\text { imbrogliatissima" }\end{array}$ \\
\hline Português & Rubens Enderle & $\begin{array}{c}4^{\mathrm{a}} \text { edição } \\
\text { alemã — } 1890\end{array}$ & 2013 & $\begin{array}{l}\text { "coisa muito } \\
\text { intrincada" }\end{array}$ \\
\hline
\end{tabular}

Fonte: Elaboração do autor.]

Não é preciso exagerar nas tintas para reconhecer que a profusão de expressão distinta, que uma mesma passagem em alemão - "verstricktes" - recebeu em suas traduções está longe de ser fruto do acaso, das idiossincrasias dos tradutores. Com efeito, o que está presente nesse caso, nas diferentes maneiras com uma expressão alemã foi traduzida, é a explicitação dos vieses políticos, ideológicos, filosóficos, que cada um de nós carrega, e que no caso de tradução significa, para o bem e para o mal, muitas vezes, independente da qualificação do tradutor, retirar o texto do 
seu leito original, pela alteração de sua dicção, de suas consonâncias, de suas afinidades. Das dez traduções listadas duas têm grande afinidade em suas sugestões metafísicas: Juan B. Justo e Pedro Scaron escolheram traduzir a expressão alemã, para "objeto endemoniado" e "cosa endiablada", lembre-se que Juan B. Justo traduziu da $4^{\underline{a}}$ edição alemã, enquanto Scaron fez sua tradução a partir da $2^{\underline{a}}$ edição alemã. A tradução mais curiosa e surpreendente, mas sugestiva e reveladora de uma dimensão central da mercadoria, sua violência, é a de Manuel Pedrosa - "cosa muy truculenta". A tradução para o francês feita por Joseph Roy, e autorizada por Marx, estabelece um certo padrão interpretativo cujo sentido básico, poder-se-á dizer, foi a minimização das ressonâncias filosóficas do texto, sua aproximação da linguagem corrente da ciência, traduzindo a expressão alemã para "chose três complexe", Roy inaugurou um filão que reúne Wenceslao Roces - "objetos muy intrincados"; Regis Barbosa e Flávio Kothe - "coisa muito complicada", Rubens Enderle - "coisa muito intrincada". A tradução inglesa de Samuel Moore e Edward Aveling e a tradução portuguesa de Reginaldo Sant'Anna convergem em agregar à expressão um certo ar de mistério - "very queer thing" e "algo muito estranho". Registre-se que a palavra inglesa queer assumiu, contemporaneamente, ainda maior complexidade na medida de sua utilização pela cultura transgênero. Finalmente, a tradução italiana de Roberto Fineschi, destaca-se pelo superlativo que usa - "cosa imbrogliatissima" - que acaba agregando ao texto uma camada a mais de expressividade.

"O livro mais importante do nosso tempo", disse Pedro Scaron de $\boldsymbol{O}$ Capital. Em que sentido? Em vários, é certo. Mas, sobretudo, porque continua sendo o instrumento mais percuciente, tanto para compreender o mundo contemporâneo, quanto para superá-lo mediante ação crítico-prática emancipatória, que reclamando-se socialista não hesita em reconhecer, tanto as fragilidades teóricas que tem padecido, e que vêm de longe, desde a época de Marx, quanto importantes descaminhos políticos, que se foram trágicos como no caso do stalinismo, não se restringiram a esta forma brutal de "socialismo de caserna", já que também grandes nomes do marxismo revolucionário, como Lênin e Trotsky, não ficaram imunes a importantes equívocos políticos.

De todo modo, o marxismo continua potente e atual em sua capacidade de apreender a realidade capitalista em sua totalidade. De tais aspectos, manifestações, que, no dia a dia dos acontecimentos, parecem fenômenos isolados, independentes, a crítica da economia política consegue explicitar suas conexões ocultas, suas determinações estruturais, como resultados da dinâmica contraditória do desenvolvimento capitalista. Tomem-se dois fenômenos, que não só no Brasil têm grande evidência, hoje em dia: a especulação e a corrupção. Tomados em si mesmos, em seus aspectos fenomênicos, especulação e corrupção parecem manifestações contingentes, estranhas ao domínio do capital, figuras transgressivas tanto da lógica da 
acumulação de capital, quanto da legalidade burguesa. Marx mostrou, em página particularmente exemplar de sua acuidade analítica, as articulações orgânicas entre especulação e corrupção como expedientes recorrentemente mobilizados pelo capital para buscar compensar os efeitos da queda da taxa de lucro. Do mesmo modo, é preciso ver tanto a corrida ensandecida do capital para destruir a natureza, quanto as várias formas de precarização do trabalho, quanto a permanente violência, imperialista, como manifestações do mesmo mecanismo geral, a busca desmesurada, de compensar a queda da lucratividade, que não hesita em lançar mão de instrumentos alheios à moralidade, à eticidade, à legalidade. Veja-se o que diz Marx: "com a queda da taxa de lucro aumenta o mínimo de capital que deve estar nas mãos de cada capitalista para o emprego produtivo do trabalho; o mínimo exigido para explorar o trabalho em geral, e ainda para que o tempo do trabalho aplicado seja o necessário para a produção das mercadorias, não ultrapassando a média do tempo de trabalho socialmente necessário para produzi-las. Ao mesmo tempo aumenta a concentração, pois, além de certos limites. Capital grande com pequena taxa de lucro acumula mais rapidamente que capital pequeno com taxa elevada. A certo nível, essa concentração crescente de capital por sua vez acomete nova queda de taxa de lucro. A massa dos pequenos capitais dispersos é assim empurrada para as peripécias da especulação, das manobras fraudulentas com crédito e ações, das crises." ${ }^{\prime 2}$.

O livro III de $\boldsymbol{O}$ Capital foi publicado em 1894, provavelmente escrito, em grande parte, entre 1864-1865, neste livro, descobrimos, desconcertados, que a relação estabelecida por Marx entre especulação - fraude com crédito e ações - crises é uma descrição precisa das peripécias do capital financeirizado, da globalização globalitária desde a década de 1980 até a "gargalhada final", entre 2006 e 2008.

Houve quem tenha associado, com razão, O Capital à Fenomenologia do Espírito, de Hegel. Menos frequente, se houve, é buscar aproximar O Capital, de Diderot, em particular de sua sátira/romance - $O$ Sobrinho de Rameau. E, no entanto, esta relação existe. Marx em resposta à sua filha, disse que seu escritor, em prosa, predileto era Diderot (17131778), grande nome da Ilustração francesa e principal responsável pela Encyclopédie, a uma das maiores realizações do espírito do século XVIII. Diderot foi importante não apenas para Marx, tendo impactado outros nomes da cultura alemã como Goethe (1749-1832) e Hegel (1770-1831). Goethe traduziu para o alemão $O$ Sobrinho de Rameau, em 1805, a partir de original manuscrito e incompleto, antes que a obra fosse publicada, integralmente, em francês, o que só veio a ocorrer em 1823. O interesse

${ }^{72}$ MARX, Karl. Para a Crítica da Economia Política. Trad. port., São Paulo, Abril Cultural. Karl Marx, 1974a, p. 288. 
por Diderot, por $\boldsymbol{O}$ Sobrinho de Rameau, também foi forte em Hegel. Este é o único texto de autor moderno citado na Fenomenologia do Espírito, de 1807, lido na tradução de Goethe. Vincenzo Cícero em sua edição da Fenomenologia do Espírito, diz: "Hegel se inspirou, amplamente, em $\boldsymbol{O}$ Sobrinho de Rameau, obra ainda desconhecida na França, para ilustrar o momento da linguagem de desagregação." (...) "Para a análise da decadência da sociedade pré-revolucionária Hegel assume como modelo literário O Sobrinho de Rameau." ${ }^{\prime 3}$.

Um especialista em Diderot, Henri Bénac, nos deu análise importante sobre o significado do livro de Diderot, diz ele: "Diderot fazia sérias reservas à solidez da ordem social em curso e previa, o que confirmariam os resultados da Revolução Francesa, uma sociedade nova, fundada unicamente no dinheiro; desta ele nos dá uma visão caricatural e burlesca, Balzac desvenda-lhe seriamente as leis, mas no fundo é da mesma coisa que se trata."74. Ou ainda, diz José Henrique Santos - "Hegel se vale da sátira de Diderot, $\mathrm{O}$ Sobrinho de Rameau, que Goethe havia traduzido em 1805, para expressar a absoluta impotência do indivíduo no trato da polis moderna..." ${ }^{\prime 75}$.

Trata-se, portanto, de ver $\boldsymbol{O}$ Capital de Marx como a apreensão abrangente e crítica, do mundo dominado pelo dinheiro, que Diderot anteviu, que Hegel analisou a partir de suas implicações sobre a liberdade do indivíduo, que Balzac inventariou em seus tipos humanos característicos, e que Marx abarcou em suas múltiplas determinações, como instrumento para a sua plena superação histórica, pela realização da liberdade e da igualdade.

\section{Bibliografia}

ARICÓ, José. Marx e a América Latina. Trad. port., Rio de Janeiro, Paz e Terra, 1982.

BALZAC, Honoré. Esplendores e Misérias das Cortesãs. Trad. port., vol. IX. A Comédia Humana. Rio de Janeiro. Porto Alegre/São Paulo, Editora Globo, 1956.

BÉNAC, Henri. "Introdução" a DIDEROT, O Sobrinho de Rameau, trad. port., Obras Romanescas II, São Paulo, Difusão Europeia do Livro, 1962.

\footnotetext{
${ }^{73}$ CÍCERO, Vincenzo. "Introduzione, traduzione, note e apparatti" a HEGEL, G. W. F. Fenomenologia dello Spirito. Trad. italiana, Milão, Edizione Bompiani, 2008, p. 1079-1080.

${ }^{74}$ BÉNAC, Henri. "Introdução" a DIDEROT, O Sobrinho de Rameau, trad. port., Obras Romanescas II, São Paulo, Difusão Europeia do Livro, 1962, p. 188.

${ }^{75}$ SANTOS, José Henrique. O Trabalho do Negativo. Ensaios sobre a Fenomenologia do Espírito. São Paulo, Edições Loyola, 2007, p. 291.
} 
BENSAID, Daniel. Marx, O Intempestivo. Grandezas e misérias de uma aventura crítica (Séculos XIX e XX). Trad. port., Rio de Janeiro, Civilização Brasileira, 1999.

BURKETT, Paul. "Some comments on 'Capital in general and the structure of Marx's capital'. In Capital $\mathcal{E}$ Class, v 44, n. 2, pp. 49-72.

CÍCERO, Vincenzo. "Introduzione, traduzione, note e apparatti" a HEGEL, G. W. F. Fenomenologia dello Spirito. Trad. italiana, Milão, Edizione Bompiani, 2008.

FAUSTO, Ruy. Marx: Lógica \& Política. Tomo I, São Paulo, Editora Brasiliense, 1983.

FINESCHI, Roberto. Un nuovo Marx. Filologia e interpretazione dopo la nuova edizione storico-critica (MEGA2). Roma, Carocci editore, 2008.

FRANCO, Carlos. "Apresentação" a ARICÓ, José. Marx e a América Latina. Op. cit.. GIANNOTTI, José Arthur. Marx. Vida E Obra. Porto Alegre, L\&PM Editores, 2000.

HEINRICH, Michael. "Prefácio - O Livro II de O Capital" in MARX, Karl. $\mathbf{O}$ Capital, Livro II, Trad. port., São Paulo, Boitempo Editorial, 2014.

KOSIK, Karel. A Dialética do Concreto. Trad. port., 2ª edição, Rio de Janeiro, Paz e Terra, 1976.

KRÄTKE, Michael. "O último Marx e O Capital” in ALIAGA, Luciana, AMORIM, Henrique e MARCELINO, Paulo (Orgs.). Marxismo. Teoria, História e Política. trad. port., São Paulo, 2011.

LANDER, Edgardo. "Marxismo, Eurocentrismo e Colonialismo" in BORON, Atilio, AMADEO, Javier e GONZÁLEZ, Sabrina (Orgs.). A Teoria Marxista Hoje. Problemas e Perspectivas. Buenos Aires/São Paulo, CLACSO/Editora Expressão Popular, 2006.

LUKÁCS, Georg. Ensaios sobre Literatura. Trad. Port., Rio de Janeiro, Editora Civilização Brasileira, 1965.

LUKÁCS, Georg. Ontologia do Ser Social. A Falsa e a Verdadeira Ontologia de Hegel. Trad. Port., São Paulo, Livraria Editora Ciências Humanas, 1979.

LUKÁCS, Georg. Ontologia do Ser Social. Os Princípios Ontológicos Fundamentais de Marx. Trad. port., São Paulo, Livraria Editora Ciências Humanas, 1979a.

MARX, Karl. Crítica do Programa de Gotha. Trad. port., Porto, Portucalense Editora, 1971.

MARX, Karl. La Ideologia Alemana. Trad. esp., 4ª . edição, Montevidéo/Barcelona, Ediciones Pueblos Unidos/Ediciones Grijalbo, 1972.

MARX, Karl. Para a Crítica da Economia Política. Trad. port., São Paulo, Abril Cultural. Karl Marx, 1974a.

MARX, Karl e ENGELS, Friedrich. Cartas sobre "El Capital". Trad. esp., Barcelona, Editorial Laia, 1974.

MARX, Karl e ENGELS, Friedrich. Materiales para la Historia da América Latina. Trad. esp., Córdoba, Cuadernos Pasado y Presente, n. 30, 1974a.

MARX, Karl. "Glosas marginales al "Tratado de economia política" de Adolph Wagner" in DOBB, Maurice e outros (orgs.). Estudios sobre "El Capital". Trad. esp., México, Espanha, Argentina, Colombia, Siglo XXI Editores, 1977. 
MARX, Karl. O Capital. Livro III, vol. 4. O Processo Global de Produção Capitalista. Trad. port., Rio de Janeiro, Civilização Brasileira, 1974b.

MARX, Karl, ENGELS, Friedrich. Imperio y Colonia. Escritos sobre Irlanda. Trad. esp., México, Cuadernos Pasado y Presente, n. 72, 1979.

MARX, Karl, ENGELS, Friedrich. La Cuestión Nacional y la formación de los Estados, Trad. esp., México, Cuadernos Pasado y Presente, n. 69, 1980.

MARX, Karl, ENGELS, Friedrich. La Revolución en España. Trad. esp., Moscou, Editorial Progreso, 1980a.

MARX, Karl. "La Respuesta a Zasulich" in SHANIN, Theodor. El Marx Tardio y la Via Rusa. Marx y la periferia del capitalismo. Trad. esp., Madrid, Editorial Revolución, 1990 (org.).

MARX, Karl. Le Capital. Livre 1. Trad. francesa, tradução de Joseph Roy, Paris, Flammarion, 1969.

MARX, Karl. Capital. A Critique of Political Economy. The Process of Capitalist Production. Trad. inglesa, tradução de Samuel Moore and Edward Aveling, New York, The Modern Library, 1906.

MARX, Karl. El Capital. Edição completa dos três livros, trad. esp., Livro I, Tradução de Juan B. Justo, Buenos Aires, Biblioteca Nueva, 1946.

MARX, Karl. El Capital. Livro I, Tomo I, trad. esp., tradução de Manuel Pedroso, México, Ediciones Fuente Cultural, 1945.

MARX, Karl. El Capital. Livro I. trad. esp., 8 (a $^{\mathrm{a}}$ reimpressão, tradução de Wenceslau Races, México, Fondo de Cultura Económica, 1973.

MARX, Karl. O Capital, Livro I, vols. 1 e 2, trad. port., tradução de Reginaldo Sant'Anna, Rio de Janeiro, Civilização Brasileira, 1968.

MARX, Karl. El Capital. Tomo I/Vol. 1, Libro I. O Proceso de Producción del Capital. Trad. esp., tradução de Pedro Scaron. 5a edição, México, Espanha, Argentina, Siglo XXI Editores, 1977a.

MARX, Karl. O Capital, Livro I, vol. 1, trad. port., tradução de Regis Barbosa e Flávio Kothe, 1983.

MARX, Karl. Il Capitale. Critica delleconomia politica. Libro primo. Il processo di produzione del capitale (1863-1890), tradução italiana, tradução de Robert Fineschi, Napolis, La cittá del Sale, Editori Rimonti, 2008.

MARX, Karl. O Capital. Livro I. O Processo de Produção do Capital, trad. port., tradução de Rubens Enderle, São Paulo, Boitempo Editorial, 2013.

NICOLAIEVSKI, Boris, MENCHEN-HELFEN, Otto. La vie de Karl Marx. Trad. Francesa, Paris, Gallimard, 1970.

PAULA, João Antonio. Crítica e Emancipação Humana. Ensaios Marxistas. Belo Horizonte, Autêntica Editora, 2014.

RONÁI, Paulo. "Introdução" a Esplendores e Misérias das Cortesãs in BALZAC, Honoré de. Op. cit., 1956.

ROSDOLSKY, Roman. Gênese e Estrutura de O Capital de Karl Marx. Trad. port., Rio de Janeiro, EDUERJ/Contraponto, 2001. 
RUBEL, Maximilien. "Notice" in MARX, Karl. Ouvres Economie I (org.) RUBEL, Maximilien, Paris, Bibliothèque de la Pléiade, NRF, Gallimard, 1965.

RUBIN, Isaak. Ensayos sobre la Teoria Marxista del Valor. Trad. esp., Buenos Aires, Cuadernos Pasado y Presente, n. 53, 1974.

SAINZ DE ROBLES, Federico Carlos. Ensayo de un Dicionario de la Literatura. Tomo I, Madrid, Aguilar Ediciones, 1949.

SANDERS, Jonathan. "La escena rusa: Nota biográfica" in SHANIN, Theodor. El Marx Tardio y la Via Rusa. Op. cit., 1990.

SANTOS, José Henrique. O Trabalho do Negativo. Ensaios sobre a Fenomenologia do Espírito. São Paulo, Edições Loyola, 2007.

SCARON, Pedro. "A modo de Introducción" in MARX, Karl e ENGELS, Friedrich. Materiales para la Historia de América Latina, op. cit., 1974a.

SCARON, Pedro. "Advertencia del Traductor" in MARX, Karl. El Capital, Tomo I/ Vol. 1, Livro I, El Proceso de Producción del Capital, México, Espanha, Argentina, op. cit., 1977a.

SHANIN, Theodor. El Marx Tardio y la Via Rusa. Op. cit., 1990.

VEDDA, Miguel. La Sugestión de lo concreto. Estudios sobre Teoria Literaria Marxista. Buenos Aires, Editorial Gorla, 2006.

WADA, Haruki. "Marx y le Rusia revolucionaria" in SHANIN, Theodor. El Marx Tardio y La via Rusa, op. cit., 1990.

Endereço do Autor:

Universidade Federal de Minas Gerais

Faculdade de Ciências Econômicas

Centro de Desenvolvimento e Planejamento Regional

Av. Antonio Carlos, 6627 - Pampulha

31270-901 Belo Horizonte - MG

jpaula@cedeplar.ufmg.br, 